\title{
Public Problems, Private Answers: Reforming Industry Self-Governance Law for the 21st Century
}

\author{
Stephen M. Maurer *
}

CONTENTS

I. Introduction................................. 299

II. Private Power, Private Politics............... 300

III. The New Private Power ..................... 302

A. The First Hundred Years.................. 302

B. Pioneers: Dolphin Safe Tuna................. 305

C. Private Regulation: Food Safety ................ 306

D. Rule by Technocrats: Fisheries ................ 311

E. A Private Legislature: Coffee.................. 315

F. Politics as Standards: Forestry................ 321

IV. Theory of Private Politics (I): Perfect

INFORMATION .................................. 330

A. Private Power and Voting Rules ............... 331

B. Private Politics: The Players .................. 333

C. Interactions With Government................ 335

V. Theory of Private Politics (II): Incomplete

INFORMATION ................................. 337

A. Imperfect Information and "Unbalanced"
Standards ................................ 337

B. Internal Politics .............................. 339

C. External Politics ........................... 340

VI. Current Law ................................ 340

A. Common Law .............................. 341

B. The Sherman Act(I): Protecting Markets .......... 343

C. The Sherman Act (II): Protecting Democracy ...... 351

D. FOGA's Shadow............................ 355

* J. Goldman School of Public Policy, University of California at Berkeley. smaurer@berkeley.edu. The author wishes to thank Robert Cooter, Sebastian v. Engelhardt, Daniel Farber, Alex Hamilton, Astrid Hopfensitz, Gretchen Hund, Hoo Ri Kim, Andrew Kurzrok, Thomas P. Lyon, Karl Riesenhuber, Paul Seabright, Amy Seward, Karine van der Straeten, Hilary Sutcliffe, Jean Tirole, and David Vogel for helpful comments. Most of the work reported in this article was performed while the author held a joint appointment at the Berkeley Law School and was a visiting scholar at the Institute for Advanced Studies in Toulouse. 
VII. Reforming Private Governance Laws .......... 356

A. Rationalizing Antitrust Law .................. 356

B. Assessing Legitimacy....................... 359

VIII. Conclusion ................................. 360

\begin{abstract}
For the past twenty years, large corporations have routinely developed and enforced industry-wide standards to address problems that are only distantly related to earning a profit. This includes writing detailed private regulations for environmental protection, national security, working conditions, and other topics formerly reserved to governments. At the same time, the Supreme Court has said that the Sherman Act forbids any "extra-governmental agency" that "provides extra-judicial tribunals for the determination and punishment of violations." 1 On the face of things, this seems to ban private rules altogether. Despite this, many U.S. policymakers continue to argue that private standards are efficient and desirable. Many corporations are sympathetic but fear legal liability and are reluctant to participate unless and until the law is clarified.
\end{abstract}

This article asks how existing law can be reformed to arrive at principled rules for deciding when private standards violate the Sherman Act. We begin with an historical account of recent private initiatives to regulate food processing, fisheries, forestry, and coffee production. We argue that these private rules are often just as effective as government regulation. We then generalize from this evidence to explain when and how large corporations are able to impose their preferences through industry-wide standards. We also describe the politics that determines how large corporations use this power. We argue that the need to earn positive profit and defend market share frequently encourages-and sometimes forces-large companies to choose standards that please consumers. In these cases, consumers act as a shadow electorate that constrains private power in much the same way that real voters constrain elected officials. Finally, our examples show that big corporations often decide to share power with smaller rivals, suppliers, NGOs, and other stakeholders. We argue that these delegations are genuine and make private standards more accountable.

The article concludes by asking how current law can be reformed. We argue that the Sherman Act serves two goals. The first is economic efficiency. We argue that private standards advance this goal by addressing problems ("externalities") that lack well-defined market prices. We argue that private bodies should be allowed to address such problems in the first instance knowing that government may later step in to change or supplement policy. The second goal is to

1. Fashion Originators' Guild, Inc. v. FTC, 312 U.S. 457, 465 (1941). 
protect democracy from private power. We argue that this danger is minimal so long as: (a) market structure encourages corporations to make choices that please consumers and other shadow electorates; (b) the standard setting body represents a wide range of affected stakeholders; or (c) industry selects the prevailing standard from multiple competing proposals. Significantly, all of these tests can be determined from objective evidence without obscure inquiries into when private power becomes "illegitimate" or poses "a threat" to democratic politics.

\section{INTRODUCTION}

Industry self-governance has grown explosively over the past two decades. In the process, big corporations have begun to regulate problems that are only distantly related to earning a profit. This includes writing private regulations for environmental protection, national security, working conditions, and other topics formerly reserved to governments. The law has not kept up. Seventy years ago, the Supreme Court declared that the Sherman Act bans any "extra-governmental agency" that "provides extra-judicial tribunals for [the] determination and punishment of violations."2 This rule was simple but unrealistic. Industry had, after all, been operating "extra-governmental" tribunals and agencies since the 1890 s. Most were facially reasonable and many markets would have collapsed without them. Worse, private standards were the wave of the future: By the 1980s, 100,000 people were writing and enforcing private rules. ${ }^{3}$ Presumably, most of these standards were lawful, but it was hard to say which ones or why.

Today, government officials acknowledge that private standards often work better than public ones. Yet these same officials complain that "rigid, exaggerated, or outdated interpretations" of antitrust law keep many companies from participating. ${ }^{4}$ Meanwhile, regulators want more private standards-and try to entice business by promising to ignore Supreme Court holdings that are still on the books. This is both unconvincing and unprincipled. Doing better will require clear rules for deciding when private governance does and does not advance democratic values.

This article asks how U.S. law should manage the new self-governance. Part II introduces a framework for thinking about private power and the politics that drive it. Part III profiles five recent (and

2. Id.

3. Joseph Farrell \& Garth Saloner, Coordination Through Committees and Markets, 19 RAND J. ECON. 235, 235 (1988).

4. See infra Section III.E. 
very ambitious) experiments in private power. Parts IV and V generalize from these examples to present a theory of private power and private politics. We emphasize how private governance institutions differ from-and sometimes improve on-traditional government as vehicles for democratic action. Part VI describes the massive but under-theorized case law on private self-governance. Part VII extends these precedents within a new framework for deciding when private power should receive deference. Part VIII presents a brief conclusion.

\section{Private Power, Private Politics}

Power is classically defined as the ability to influence or, less politely, impose one's will on others. ${ }^{5}$ Significantly, the definition does not distinguish between governments and private actors. This section introduces the idea of private power and private politics.

Markets and Choice. We start by acknowledging the obvious: Private power is the exception, not the rule. Indeed, the institution most associated with the private sector-competitive markets-is the very opposite of power. If $\mathrm{A}$ wants to help the environment she can buy green energy from $\mathrm{B}$. But this is an act of individual choice or charity: If $\mathrm{C}$ wants to buy dirty coal-fired energy from $\mathrm{D}$ there is nothing to stop him. In practice, many private standards are designed to facilitate this kind of choice. For example, A may not be able to tell whether the energy she buys is green or not. Here, the obvious solution is to make the market more efficient by developing private standards that provide this information. ${ }^{6}$ There is now a large literature on how choice operates and is sometimes distorted or manipulated in imperfect markets. ${ }^{7}$

Private Power. Governments follow a different model: Once Congress passes a green energy statute, A and B can still have their trans-

5. Robert A. Dahl, The Concept of Power, 2 BehAv. ScI. 201, 202-203 (1957) ("My intuitive idea of power then, is something like this: $A$ has power over $B$ to the extent that he can get $B$ to do something that $B$ would not otherwise do."); Tim Büthe, Global Private Politics: $A$ Research Agenda, Bus. \& Pol., Oct. 2010 at 1 (defining "private politics" as “'attempt[s] to impose [one's] will on others' without relying on 'lawmaking or courts", (quoting David P. Baron, Private Politics, 12 J. Econ. \& Mgmt. Strategy 31, 31 (2003)).

6. For a formal microeconomic model of how private standards empower individual choice, see Timothy Besely \& Maitreesh Ghatak, Retailing Public Goods: The Economics of Corporate Social Responsibility, 91 J. Pub. ECON. 1645 (2007).

7. See, e.g., Carolyn Fischer \& Thomas P. Lyon, Competing Environmental Labels, 23 J. EcoN. \& MGMT. STRATEgy (forthcoming Fall 2014) (surveying literature on market choice where standards are few in number or poorly trusted and understood by consumers), available at http:// webuser.bus.umich.edu/tplyon/PDF/Published\%20Papers/Fischer\%20Lyon\%20JEMS\%20Revision \%20Doublespaced\%20with\%20Figures.pdf. 
action, but $\mathrm{C}$ and $\mathrm{D}$ cannot. To be meaningful, private power must similarly find a way to frustrate $C$ and D's transaction. We will see that this is often possible in imperfect markets where demand is dominated by a few large actors. ${ }^{8}$ Strangely, this economic coercion is frequently exerted through the same private standards that empower consumer choice. Recent scholarship emphasizes that real standards often blend choice and compulsion and that this mix can evolve over time. ${ }^{9}$

Private Politics. We will see ${ }^{10}$ that individual firms hardly ever possess enough economic power to impose their will on an entire industry. Instead, several firms must first agree on a standard. In the language of politics, this establishes a voting rule for deciding when private standards become binding.

We know from conventional politics that many voting rules are possible. Familiar examples include majority rule, supermajorities, and constitutional prohibitions against certain laws. The main difference is that private voting rules-unlike public ones-are set by accidents of market structure and not legislated. Ex ante, there is no reason to think that any of these rules is legitimate. ${ }^{11}$ Ex post, we will see that large corporations often delegate their authority to NGOs, suppliers, and other outside actors. This delegation necessarily creates new and less accidental rules.

The Case for Private Governance. The fact that private actors can exercise power does not mean that they should. In theory, government could provide all the collective action that society needs. However, government's ability to intervene is limited. First, government officials have limited resources and attention span. At any given time most problems will go unregulated unless and until the private sector steps in. ${ }^{12}$ And when government does regulate, private solutions are often faster. ${ }^{13}$ Second, governments have limited ability to monitor

8. For full economic details, see infra Part IV and the references cited therein.

9. See, e.g., Eric Brousseau \& Emmanuel Raynaud, Climbing the Hierarchical Ladders of Rules: A Life-Cycle Theory of Institutional Evolution, 79 J. ECON. BEHAv. \& ORG. 65, 65-67 (2011) (describing how voluntary standards can become mandatory and even be subsumed into government).

10. See infra Section III.

11. Supermajorities enforce a kind of legitimacy by guaranteeing that no action is ever taken without widespread support. This is offset by the fact that simple majorities are routinely disenfranchised.

12. See Robert Pitofsky, Chairman, Fed. Trade Comm'n, Address at the D.C. Bar Ass'n Symposium: Self-Regulation and Antitrust (Feb. 19, 1998) ("Finally, government resources are limited and unlikely to grow in the future. Thus, many government agencies, like the FTC, have sought to leverage their limited resources by promoting and encouraging self-regulation.").

13. $I d$. 
compliance. This is especially true for events that take place in complex domestic markets ${ }^{14}$ or beyond national borders. ${ }^{15}$ These disabilities are still greater in the developing world. ${ }^{16}$ Finally, government regulators have limited information about how to intervene. ${ }^{17}$ This makes government solutions more expensive than they need to be.

Private governance relaxes these limitations and expands the number of options open to society. At the same time, these options are only beneficial when choice is legitimate. Within the European tradition, this implies that private politics should be reasonably democratic, i.e. follow procedures designed to empower widely held values and goals. We return to this subject in Sections IV and V.

\section{The New Private Power}

American industry has practiced self-governance since the Nineteenth Century. These institutions have expanded and become dramatically more ambitious since the 1990s.

\section{A. The First Hundred Years}

The story of private governance begins with the rise of Big Business in the late Nineteenth Century. ${ }^{18}$ One early example involved insurance. In theory, the new nationwide capital markets let factory own-

14. Tim Buthe \& Walter Mattli, The New Global Rulers: The Privatization of REGULATION IN THE WORLD ECONOMY 25 (2011) ("Private governance has been encouraged by the "excruciatingly slow pace of standards production" by state bodies "and, in some cases, lack of the technical expertise and financial resources."); Id. at 5 (describing how EU delegated manufactured goods standards to private sector because official negotiations were taking too long).

15. Tim Büthe, Private Regulation in the Global Economy: A (P)Review, Bus. \& Pol., Oct. 2010, at 5-6 (describing decade-long delays in negotiating international standards for pesticides, financial reporting, and manufacturing); Frederick Mayer \& Gary Gereffi, Regulation and Economic Globalization: Prospects and Limits of Private Governance, Bus. \& Pol., Oct. 2010, at 1-2 (International regulatory standards are generally weak and hard to enforce).

16. Mayer \& Gereffi, supra note 15 , at 4 . (Developing governments "lacked the ability, and to some extent the will, to regulate production.").

17. Pitofsky, supra note 12 ("[S]elf-regulation can bring the accumulated judgment and experience of an industry to bear on issues that are sometimes difficult for the government to define with bright line rules."); see also Jon Leibowitz, Comm'r, Fed. Trade Comm'n, The Good, the Bad and the Ugly: Trade Associations and Antitrust (Mar. 30, 2005) ("Simply put, self-regulation allows those who know the industry best to help set the rules of the game."); see also, Cass R. Sunstein, Winner-Take-Less Codes: The Case of Private Broadcasting, 6 UnIv. CHI. L. ScH. ROUNDTABLE 39 (1999) ("Government regulation is often the response to market failure, but a code might be better, especially because of its comparative flexibility and because of the informational advantages of private enforcers ... direct regulation may lead the industry to provide benefits more crudely and expensively than if a code were in place.").

18. As usual, there were precedents. During the Middle Ages, the University of Paris used its massive purchasing power to insist that bookstores stop selling books that offended the Church or State. George Haven Putnam, Books and their Makers During the Middle Ages 199-201 (1896). 
ers spread risk. In practice, investors still needed to satisfy themselves that insureds met certain minimum safety standards. Otherwise, reckless insureds could quickly overwhelm the industry through adverse selection. The insurance industry fixed this potentially fatal market defect by creating a private legislature to write rules and a private agency to enforce them. ${ }^{19}$ Other early schemes addressed market flaws connected with experience goods, ${ }^{20}$ transactions costs, ${ }^{21}$ and interoperability. ${ }^{22}$

These standards were fairly easy to enforce. After all, industry would collapse without them. Over time, however, firms started trying to impose private standards on markets that were already stable. One obvious strategy was to ask government to give private standards the force of law or, less formally, threaten regulation if industry failed to regulate itself. ${ }^{23}$ However, such strategies only work where govern-

19. See Franco Furger, Accountability and Systems of Self-Governance: The Case of the Maritime Industry, 19 Law \& PoL'Y 445 (1997) (describing how Underwriters Laboratories and Factory Mutual regulated product design and manufacturing operations). It is conventional to argue that insureds voluntarily agree to private tribunals when they decide to purchase insurance. This is a thin distinction for industries where firms need insurance to earn a profit or stay in business.

20. See Andrew King \& Michael Lenox, Industry Self-Regulation Without Sanctions: The Chemical Industry's Responsible Care Program, 43 ACAD. MGMT. J. 698 (2000) (describing private regulation of books and movies); David A. Garvin, Can Self-Regulation Work?, 25 CAL. Mgmt. Rev. 37 (1983) (describing private standards for doctors, lawyers, and other professionals).

21. Chris Doyle, Self Regulation and Statutory Regulation, 8 Bus. Strategy Rev. 35 (1997); see Garvin, supra note 20.

22. Garvin, supra note 20, at 44-45; Tim Büthe, Engineering Uncontestedness? The Origins and Institutional Development of the International Electrotechnical Commission (IEC), Bus. \& Pol., Oct. 2010, at 22.

23. This could be done in various ways. The most obvious was explicit government regulation and legislation. Anil K. Gupta \& Lawrence J. Lad, Industry Self-Regulation: An Economic, Organizational, and Political Analysis, 8 ACAD. MGmT. 416 (1983) (securities dealers and accounting standards); King \& Lenox, supra note 20, at 716 (pollution and public safety standards for manufacturing); Furger, supra note 19; Tim Buthe, Private Regulation in the Global Economy: Guest Editor's Note, Bus. \& Pol., Oct. 2010, at 15-16 (broadcasters and Canadian medical devices). Government could also elicit action by threatening to intervene in the future. King \& Lenox, supra note 20; Darren Sinclair, Self-Regulation Versus Command and Control? Beyond False Dichotomies, 19 LAw \& PoL'y 529 (1997) (describing private greenhouse gas regulation in U.S. and New Zealand); Daniel J. Fiorino, Voluntary Initiatives, Regulation and NaNotechnology Oversight: Charting a PATH 19, available at http://www nanotechproject. org/process/assets/files/8347/pen-19.pdf (listing EPA-sponsored initiatives); William A. Pizer, Richard Morgenstern \& Jhih-Shyang Shih, Evaluating Voluntary Climate Programs in the United States 8-13 (Resources for the Future Discussion Paper 2008), available at http://www.rff.org/ RFF/Documents/RFF-DP-08-13.pdf. Finally, many industries self-regulated because they were convinced that failure to act would invite still more onerous government intervention. Gupta \& Lad, supra note 24 (quoting AHAM's technical director: "[T]he only way to avoid government regulation is to move faster than the government [through] judicious self-regulation."); see also, Michael J. Lenox \& Jennifer Nash, Industry Self-Regulation and Adverse Selection: A Compari- 
ment cared strongly about an issue. This meant that industry often ended up doing the government's bidding. ${ }^{24}$

A better solution took advantage of large firms' power over their trading partners. ${ }^{25}$ The most important early example was the Fashion Originator's Guild of America (FOGA), ${ }^{26}$ whose members produced $60 \%$ of all quality womenswear sold in the U.S. ${ }^{27}$ In the 1930s, FOGA announced that its members would stop selling to any retailer that it determined to be "unethical." 28 Since most retailers needed members' products to stay competitive, ${ }^{29}$ at least 12,000 retailers promptly agreed to "cooperate." 30 Soon, FOGA was running a parallel government that included offices for registering intellectual property, ${ }^{31}$ monitoring retailers, ${ }^{32}$ and conducting trials and appeals. ${ }^{33}$ This was too much for the Supreme Court, which struck down the arrangement on grounds that the Sherman Act barred "extra-governmental agenc[ies]." 34

son Across Four Trade Association Programs, 12 Bus. Strategy \& Env't 343, 344 (2003) (quoting Kodak's CEO: "[I]f industry doesn't take the lead on this issue, government will."); Büthe, supra note 15, at 20 (nuclear power self-regulation was motivated by desire to preempt government standards); and Gupta \& Lad, supra note 23 (documenting how fears of government intervention led to accounting, Underwriters Laboratories, and baby food standards).

24. Theorists who model private governance as a "shadow of hierarchy" argue that private actors preferences should be viewed as a (generally modest) correction to official policy. $\mathrm{Na} \mathrm{Li}$ Dawson \& Kathleen Segerson, Voluntary Agreement With Industries: Participation Incentives With Industry-Wide Targets, 84 Land Econ. 97 (2008); Peter M. DeMarzo, Michael J. Fishman, \& Kathleen M. Hagerty, Reputations, Investigations, and Self-Regualation, (Sept. 2007) (preliminary and incomplete), available at http://www.kelley.indiana.edu/Finance/Research/seminarseries/files/fishman07.pdf.

25. For full economic details, see infra Section IV.A.

26. Fashion Originators' Guild, Inc. v. FTC, 312 U.S. 457 (1941).

27. Id. at 462 .

28. Id. at 461. FOGA's standards attempted to outlaw copying of original dress designs, contributing funds to retailers' ad campaigns, offering certain discounts, holding special sales, selling directly to the public, selling in private homes, and holding fashion shows where no merchandise was purchased or delivered. Id. at 463.

29. Id. at 462 .

30. More than half protested that they had been coerced. Id. at 461-62.

31. Designs were protected in two private registration offices. Fashion Originators' Guild, Inc., 312 U.S. at $462-63$.

32. FOGA hired professional shoppers to find stores carrying pirated designs. Id. It also conducted periodic audits and assessed fines against members who sold to blacklisted retailers. Id. at 463 .

33. Id. at $462-63$.

34. Id. at $465-66$. 


\section{B. Pioneers: Dolphin Safe Tuna}

The rise of global supply chains in the 1980s enormously expanded retailers' power. ${ }^{35}$ At the same time, growing consumer pressure encouraged dominant firms to use their power for public purposes. The earliest example involved dolphin-safe tuna. Naively, one might have expected the three big tuna buyers to control suppliers in proportion to their purchases. This would have led to controls on perhaps half the fishing fleet. In fact, the standard became universal.

History. Consumers became concerned that tuna fishermen were killing dolphins in the 1980s. ${ }^{36}$ In 1990, NGO Earth Island partnered with Star Kist, the world's largest tuna processor, to develop "Dolphin Safe" standards. ${ }^{37}$ These were promptly endorsed by Star-Kist's main rivals, Chicken of the Sea and Bumble Bee. Together, the Big Three controlled $84 \%$ of the U.S. canned tuna market, ${ }^{38}$ which made up half of the world market. ${ }^{39}$

In a perfect market, other buyers would have been free to reject the Big Three's standard. But this ignores suppliers' need to preserve economies of scale. Once the Big Three had spoken, maintaining separate facilities for non-compliant tuna became impractically expensive. By 2011, more than 471 companies in sixty-seven countries had

35. The power of domestic supply chains had been clear for years. See, e.g., Or. Rest. \& Beverage Ass'n v. United States, 429 F.2d 516 (9th Cir. 1970) (Tavern owners association forced suppliers to halt direct sales to the public); Tropic Film Corp. v. Paramount Pictures Corp., 319 F.Supp. 1247, 1249 (S.D.N.Y. 1970) (Nine companies that produced and distributed "a very substantial majority of the films shown in this country" established private rules regulating who could see movies); United States v. Nat'l Ass'n of Broadcasters, 536 F. Supp. 149 (D.D.C. 1982) (Three large networks regulated ads shown to $85 \%$ of all TV viewers).

36. Elise Golan, Fred Kuchler \& Lorainne Mitchell, Economics of Food Labeling, 24 J. ConSUMER POL'Y 117, 155 (2001).

37. Golan, Kuchler \& Mitchell, supra note 36, at 155; see also Tim Carman, WTO: 'DolphinSafe' Label Discriminates Against Mexico, Wash. Post All We Can Eat Blog (May 16, 2012), http://www.washingtonpost.com/blogs/all-we-can-eat/post/wto-dolphin-safe-label-discriminatesagainst-mexico/2012/05/16/gIQAwnCcUU_blog.html. "Dolphin Safe" standards outlaw, among other things, the "intentional chasing, netting or encirclement of dolphins during an entire tuna fishing trip"; the use of drift gill nets; accidental killing or serious injury to dolphins during net sets; and mixing dolphin-safe and dolphin-deadly tuna in individual boat wells or processing facilities. International 'Dolphin Safe' Standards For Tuna, EARTH IsLand InST. (last visited May 13, 2014), http:/www.earthisland.org/immp/Dol_Safe_Standard.html [hereinafter International Standards]. The rules also require companies to pay for an independent observer each time vessels exceeding 400 gross tons enter the Eastern Tropical Pacific. Id. All procurement records and processing, storage, and transshipment facilities must similarly be open to monitoring. Id.

38. Golan, Kuchler \& Mitchell, supra note 36, at 155; see also Carman, supra note 37 (Big Three market share is "more than $80 \%$.").

39. Golan, Kuchler \& Mitchell, supra note 36, at 158; The Tuna Boycott That Led to the Dolphin Safe Label, European Cetacean ByCatch Campaign (last visited May 13, 2014), http://www.eurocbc.org/page322.html [hereinafter Tuna Boycott]. 
joined the scheme. ${ }^{40}$ The result was a kind of miniature government in which industry paid Earth Island to inspect canneries, docks, and fishing vessels. ${ }^{41}$

Interactions with Government. Government's relation to the private initiative was complex. On the one hand, suppliers knew that adopting the Big Three standard would help them avoid U.S. diplomatic pressure and trade embargoes. This helped spread the private standard. ${ }^{42}$ On the other, the private standard remained independent ofand sometimes conflicted with-the "official" U.S. standard that Congress created in November $1991 .{ }^{43}$ It was also more durable: Worldwide fishing practices barely changed when the World Trade Organization struck down the U.S. standard in 2012.44

Effectiveness. The private dolphin safe standard was remarkably effective. Indeed, it is hard to see how conventional treaties or statutes could have done better. NGOs report that the private standard virtually eliminated dolphin-deadly tuna from " $90 \%$ of the world's canned tuna markets," including Europe, Canada, and Australia. By 1997 only $2.9 \%$ of the world's tuna supply was caught by chasing and setting nets on dolphins, and dolphin mortality had dropped $97 \%$ compared to the $1980 \mathrm{s.}{ }^{45}$

\section{Private Regulation: Food Safety}

Dolphin-safe tuna rules were simple enough to be written down on a single piece of paper. The next self-governance experiment showed

40. Adopters include the U.S. Tuna Foundation, commercial fishermen, small canneries, brokers, import associations, retail stores, and restaurant chains. Golan, Kuchler \& Mitchell, supra note 36, at 155; see also Carman, supra note 37; International Standards, supra note 37; Approved Dolphin-Safe Tuna Processing Companies \& Fishing Companies, EARTH IsLAND Inst. (last visited May 13, 2014), http://www.earthisland.org/dolphinSafeTuna/DolphinSafeCanners.html.

41. Tuna Boycott, supra note 39. See also, EARTh IsLAND INST., INTERnATIONAL Tuna MonItoring Program 2011 AnNual RePORT 7 (2011), available at http:/www.earthisland.org/ dolphinSafeTuna/assets/2011MonitorReport.pdf (Earth Island performed 493 inspections in 2011).

42. Golan, Kuchler \& Mitchell, supra note 36 , at 158.

43. Id: 16 USC $\$ 1385$ (2006). Earth Island even called for a consumer boycott of the Commerce Department standard. International Dolphin Safe Monitoring Program, EARTH IsLAND INST. (last visited May 13, 2014), http:/www.earthisland.org/dolphinSafeTuna/.

44. Dispute Settlement, United States - Measures Concerning the Importation, Marketing and Sale of Tuna and Tuna Products, WT/DS381 (May 16, 2012), available at https://www.wto.org/ english/tratop_e/dispu_e/cases_e/ds381_e.htm; Carman, supra note 38.

45. International Standards supra note 38; Michael E. Conroy, Branded!: How the 'CeRtification Revolution' is Transforming Global Corporations 46 (2007); Tuna Boycott, supra note 39 (Dolphin mortality in the Eastern Tropical Pacific fell from " $80-100,000$ annually in the late 1980 's, to under 3,000 dolphins annually today."). 
that industries could design and enforce the kind of complex regulatory codes normally associated with government.

History. Many large European supermarkets responded to "Mad Cow Disease" by imposing detailed handling and inspection requirements on their suppliers. ${ }^{46}$ For their part, suppliers-who typically faced "a huge retailer they can't afford to lose" 47 - hardly ever resisted. At the same time, the proliferation of standards forced suppliers to maintain multiple overlapping inventory and compliance systems ${ }^{48}$ and limited the number of suppliers who could bid for orders. ${ }^{49}$ This created an obvious financial incentive to unify the various individual retailers' rules within a single code.

In 1996, the Association of UK Retailers began work on an industry-wide food code. ${ }^{50}$ This was promptly adopted throughout the UK $^{51}$ and Holland. ${ }^{52}$ Similar retail food association initiatives produced the German/French "International Food Standard" (IFS) in

46. GFSI Guidance Document Sixth Edition Overview, Global Food Safety InItiative (last visited May 13, 2014), http://www.mygfsi.com/technical-resources/guidance-document.html (GFSI was organized in response to "several high-profile recalls, quarantines, and the associated negative publicity.").

47. Rhonda Wellik, Global Food Safety Initiative Improves Organizational Culture, Efficiency in Food Industry, Food QuALITY \& SAFETY Apr./May 2012, available at http://www.foodquality. com/details/article/1721905/Global_Food_Safety_Initiative_Improves_Organizational_Culture_ Efficiency_in_Food.html?tzcheck=1; Doris Fuchs \& Agni Kalfagianni, The Causes and Consequences Private Food Governance, Bus. \& Pol., Oct. 2010, at 13 (Retail supermarkets are highly concentrated with the top five retailers controlling at least $70 \%$ of the market in most countries); Tetty Havinga, Actors in Private Food Regulation: Taking Responsibility or Passing the Buck to Someone Else?, (Nimigen Sociology of Law Working Paper Series No. 2008/1) (This purchasing power makes "retail food safety standards obligatory for all who want to stay in the [U.K.] market."); Jaap van der Kloet \& Tettty Havinga, Private Food Regulation from a Regulatee's Perspective, (Nigmegen Sociology of Law Working Papers Series No. 2008/07) (The "purchasing power of supermarkets makes retail food safety standards in fact obligatory for many manufacturers.").

48. See Wellik, supra note 47 (noting that, in one instance, adoption of a common standard reduced number of required audits from 17 to just two per year).

49. Doris Fuchs, Agni Khalfagiannini \& Maarten Arendtsen, Retail Power, Private Standards, and Sustainability in the Global Food System, in Corporate Power in Global Agrifood Governance 29, 41 (Jennifer Clapp \& Doris Fuchs eds., 2009) (Uniform standards "induce supplier participation."). Small supermarkets that adopted an idiosyncratic standard might not attract any bids at all. $I d$.

50. van der Kloet \& Havinga, supra note 47.

51. Tetty Havinga, Private Regulation of Food Safety by Supermarkets, 28 LAw \& PoL'Y 515 (2006) (All but one U.K. supermarket uses BRC).

52. Id. (Dutch retailers adopted the British Retail Consortium Standard because suppliers were "more prepared to accept that"). 
$2002-2003^{53}$ and the American "Safe Quality Food" (SQF) standard in $2003 .{ }^{54}$

Despite this progress, the existence of disparate regional standards remained a drag on long-distance trade. In 1997, thirteen large retailers created the EurepGAP (later GlobalGAP) standard to harmonize standards across Europe. ${ }^{55}$ By then, however, local and regional standards were already entrenched. Instead, GlobalGap became a de facto fourth standard, mostly in the developing world. ${ }^{56}$ By 2006, the four regional standards covered more than three-quarters of the food sold in supermarkets worldwide. ${ }^{57}$

More recent initiatives stress that there are many acceptable ways to ensure food quality. Beginning in the 1990s, many European supermarkets began to recognize more than one private standard at time. ${ }^{58}$ In 2000, a group of international retailers created a Gobal Food Safety Initiative (GFSI) to formalize the process. ${ }^{59}$ By 2006, GFSI had rec-

53. Doris Fuchs, Agni Khalfagiannini \& Tetty Havinga, Actors in Private Food Governance: The Legitimacy of Retail Standards and Multistakeholder Initiatives with Civil Society Participation, 28 Agric. \& Hum. Values 353, 356 (2008). Many Italian, Austrian, Polish, Spanish, and Swiss retailers have since adopted the standard. Id.

54. Id. U.S. Food Management Institute represents three quarters of all U.S. retail food stores and 200 companies in 50 countries.

55. Fuchs \& Kalfagianni, supra note 47 , at 4 (EurepGAP was formed to harmonize conflicting national standards.); van der Kloet \& Havinga, supra note 47; Tim Lang \& David Barling, The Environmental Impact of Supermarkets: Mapping the Terrain and the Policy Problems in the UK, in Supermarkets and Agrifood Supply Chains: Transformations in the Production AND Consumption of Foods 192, 203 (David Burch \& Geoffrey Lawrence eds., 2007); Eurep-

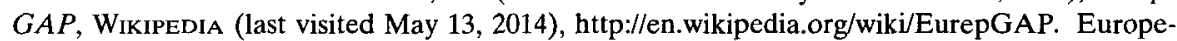
GAP has since grown to include "a Who's Who of European food retailers." Hugh Campbell \& Richard Le Heron, Supermarkets, Producers and Audit Technologies: The Constitutive MicroPolitics of Food, Legitimacy, and Governance, in Supermarkets AND AGrifood SupPly, supra note 55, at 141 .

56. van der Kloet \& Havinga, supra note 47.

57. Some estimates run as high as $99 \%$. Fuchs, Khalfagiannini \& Havinga, supra note 53 , at 356.

58. van der Kloet \& Havinga, supra note 47.

59. Fuchs, Khalfagiannini \& Arendtsen, supra note 49, at 36; Havinga, supra note 47, at 524 . GFSI Guidance Document, supra note 46 ("[T] he GFSI Guidance Document provides a template against which food safety management schemes can be benchmarked and recognised as science-based, contemporary, and rigorous. It is a tool which fulfills one of the main objectives of GFSI, that of determining equivalency between food safety management systems."). 
ognized all four regional standards. ${ }^{60}$ GFSI members currently account for sixty-five percent of worldwide retail food sales. ${ }^{61}$

Politics. The big retailers had relatively little information about their suppliers' operations. This made it hard to know which food safety rules were cost-effective and/or economically sustainable. Broadly speaking, retailers used two strategies to solve the problem.

The first strategy was to guess at an appropriate standard and then encourage suppliers to adopt it. After that, competition would spread compliance throughout the industry. Anecdotal evidence suggests that this pressure is intense. ${ }^{62}$ There is also a second level of competition: When one of the big four regional standards upgrades its procedures, the rest often feel compelled to follow.

The second strategy was superficially simpler: Just ask suppliers for advice. But there was a problem. Suppliers worried that candid disclosures could show retailers that even even harsher demands were possible. The retailers who founded GlobalGap and GFSI eliminated this concern by opening their organizations so that suppliers received roughly as many votes as retailers. ${ }^{63}$ In this case, at least, retailers seem to have decided that any loss of power was less important than acquiring the information needed to design cheaper and more effective standards.

Strikingly, GlobalGap also shared power with NGOs and consumer groups. This helped convince regulators and the public that Global-

60. In 2008, supermarket giants Tesco, ICA, Metro, Migros, Ahold, WalMart, and Delhaize endorsed the same four standards. What is GFSI?, Global Food SAFETy InItiative (last visited May, 13, 2014), http://www.mygfsi.com/about-gfsi.html (describing first edition of GFSI's 2001 Guidance Document). This encouraged still more retailers to join GFSI. Wellik, supra note 47 (Certification consultants report that "WalMart's backing was huge for GFSI."). As of 2013, GSFI had either endorsed or was in the process of reviewing eleven distinct standards. GFSI Benchmarking Process, Global Food Safety Initiative (last visited May 13, 2014), http://www.mygfsi.com/gfsi-benchmarking-general/applications-update.html.

61. Fuchs, Khalfagiannini \& Arendtsen, supra note 49 , at 36.

62. Retailer demands for GFSI alarmed retailers who "didn't know which way to turn because their system had been operating for 10 years with little change and they had not kept pace. Suddenly they faced the real prospect of losing a lot of business." Wellik, supra note 47.

63. Fuchs, Khalfagiannini \& Havinga, supra note 53, at 361 (GlobalGAP membership was expanded in 2001 to include roughly equal numbers of suppliers and retailers.); GlobalG.A.P. Technical Comittees, GLoBaLG.A.P., http://www.globalgap.org/uk_en/who-we-are/governance/ technical-committees/ (last visited May 13, 2014) (GFSI's current board is evenly dividied between suppliers and retailers). But see Agni Kalfagianni, The Effectiveness of Private Food (Retail) Governance for Sustainability, 12 InST. ENv'T STUD. 1 (2010) (arguing that GFSI is dominated by retailers and large suppliers with small producers and NGOs limited to a consultative role). The big regional standards are still dominated by retailers. Fuchs, Khalfagiannini \& Hanvinga, supra note 53, at 362 (SQF); Havinga supra note 47 (IFS and BRC). 
Gap's food safety standards were more than just "greenwashing."64 Once again, the benefits of delegation outweighed its costs.

Interactions With Government. The new private food safety standards blunted whatever political pressure had previously existed for government to regulate directly. ${ }^{65}$ In 2002 , the EU recognized the obvious by giving business primary responsibility for food safety. ${ }^{66}$ This probably made sense given the EU's limited regulatory resources, ${ }^{67}$ especially since regulators could still influence private standards informally. ${ }^{68}$

Results. Scholars agree that private food standards have produced a kind of private government ${ }^{69}$ that imposes significant costs on suppliers. ${ }^{70}$ The resulting regulations affect thousands of people around the world. ${ }^{71}$ Whether private regulation was wise is a separate issue,,$^{72}$ although recent European food scandals do not seem obviously worse than traditional regulatory failures. ${ }^{73}$

64. Campbell \& Le Heron, supra note 55 at 142.

65. Fuchs \& Kalfagianni, supra note 47 at 20 (Global Gap has prevented national food safety regulation from developing in Europe.).

66. Id. at 11; Commission Regulation 178/2002, 2002 O.J. (L 031) 1 (EC). I am grateful to Prof. Karl Riesenhuber for explaining EC regulations in this area.

67. Fuchs \& Kalfagianni, supra note $47,18 \mathrm{n} .76$ ("We cannot be certain that . . governments would have implemented superior regulation . . . in comparison to retail standards."); Buthe, supra note 15, at 5 (Even the U.S. finds it hard to regulate certain kinds of food.).

68. Havinga, supra note 51 , at 515 (describing Dutch regulatory pressure on private food inspections).

69. Büthe, supra note 5, at 13 ("[M]onopsony gives the retailers tremendous power over the food producers" which they have used to regulate "large parts of the food supply of the Western world."); Büthe, supra note 15, at 1 (Regulators "exercise power in a Dahlian sense."); Fuchs \& Kalfagianni, supra note 47 , at 10 ("[R]etail food corporations" have "the power to govern."); Havinga, supra note 52, at 529 (Private regulation is "detailed" with "a high degree of intervention curtailing freedom of regulated firms.").

70. The new standards drove many small farmers out of the market. Fuchs, Khalfagiannini \& Arendtsen, supra note 49, at 30 . ("To stay competitive ... [farmers] have to supply large volumes of food (and/or feed) per client and transaction. ... [S]mallholder farmers with small economies of scale, poor access to the market, and limited investments in inputs or infrastructure often are squeezed out."); Fuchs \& Kalfagianni, supra note 47, at 8 (Small South African farmers were driven from the market); Campbell \& Le Heron, supra note 55, at 142 (Small Australian producers consider EurepGAP to be a "large hurdle.").

71. For example, GlobalGap currently certifies 130,000 farms in 120 countries. The GlobalG.A.P. Database, GloBalG.A.P., http:/www.globalgap.org/uk_en/what-we-do/the-ggsystem/GLOBALG.A.P.-Database/ (last visited May 15, 2014).

72. Some industry experts argue that retailers still prioritize price over safety and that enforcement is lax. Havinga, supra note 51, at 528-29.

73. See, e.g., Kathy Gordon, Tesco Sees Setback as UK Sales Slip, WALL Sr. J. (June 5, 2015), http://online.wsj.com/news/articles/SB10001424127887323844804578526511506702712 (discussing Europe's recent horsemeat scandal). 


\section{Rule by Technocrats: Fisheries}

The dolphin and food safety standards were developed almost entirely within industry. This made consensus relatively easy. Inviting outside suppliers and activists to participate raises deeper challenges. The Marine Stewardship Council (MSC) tried to limit controversy by making as many value judgments as possible at the outset. After that, implementation was supposed to be objective and politics-free.

History. Government diplomacy in the 1980s established broad consensus around the concept of "sustainable fisheries" but produced little in the way of practical implementation. This convinced many NGOs to seek alternative strategies. ${ }^{74}$ Meanwhile, the collapse of the Grand Banks cod fishery provided a wakeup call for companies whose asset value dependent on reliable fish supplies. ${ }^{75}$ In 1995, Unilever invited the World Wild Life Federation (WWF) to discuss self-regulation. ${ }^{76}$ Starting in September 1996, WWF and Unilever held a yearlong series of conferences to turn the official consensus into detailed Principles that could be implemented by dispassionate experts. ${ }^{77}$ These open discussions showed that the Principles were convincingly mainstream.

MSC began operations as a fully independent entity in 1999.78 The basic challenge was to persuade individual fisheries to invest the up to $\$ 500,000$ needed for certification to join the program. ${ }^{79}$ In practice,

74. Thomas Hale, Marine Stewardship Council, in Handbook of Transnational GovernANCE: Institutions AND InNovations 308, 309 (Thomas Hale \& David Held eds., 2011) ("These regulations did not go far enough for private groups like WWF and Unilever.").

75. Rupert Howes, The Marine Stewardship Council Programme, in SEAFood Ecolabel. ling: Principles ANd Practice 81, 83 (Trevor Ward \& Bruce Philips eds., 2008). Prominent scientific predictions that world fisheries would collapse by mid-century further persuaded Unilever that sustainable fishing was needed to protect its asset value. $I d$. at 81 .

76. Dave Wortman, Shop and Save, Sierra Mag. (Nov./Dec. 2002), http://www.sierraclub. org/sierra/200211/ecolabels.asp.

77. The "Principles" were drafted at an experts' workshop in September 1996 and followed by eight meetings where stakeholders around the world were invited to comment and suggest changes. A second experts' workshop finalized the document in December 1997. Howes, supra note 77, at 84; Hale, supra note 76, at 309. WWF and Unilever split FSC's \$1 million-plus startup costs equally. Brendan May, Duncan Leadbitter \& Michael Weber, The Marine Stewardship Council (MSC), in Ecolabelling in Fisheries: What Is It All About? 14 (Bruce Phillips, Trevor Ward \& Chet Chaffee eds., 2008). Participants included government scientists, activists, marine conservationists, academics, and industry. No fishermen were consulted. See Wortman, supra note 76.

78. Unilever Corp., Fishing for the Future II: Unilever's Fish Sustainability InitiaTIVE (FSI) 8 (2003).

79. May et al., supra note 77 ; Hale, supra note 74 , at 311 . For a slightly lower estimate see Howes, supra note 75 , at 88 (quoting certification fees ranging from $\$ 20,000$ for small community fisheries to "perhaps $\$ 200,000$ to $\$ 300,000$ for the largest fisheries"). The figure does not include the cost of whatever new or additional practices are required for certification. For comparison, 
fisheries joined for two distinct reasons. First, some consumers were willing to pay a sustainability premium for certain high-end species, like salmon. ${ }^{80}$ By 2006 , MSC had certified more than $42 \%$ of the salmon worldwide catch, ${ }^{81}$ and salmon accounted for about $15 \%$ percent of all MSC-certified seafood.

The second set of adoptions was driven by oligopoly competition. Many consumers will cheerfully switch brands to buy sustainable fish-but only if the price stays constant. This means that big fish processors can use sustainability to grab market share from rivals, provided that they and/or their suppliers (a) earn above-normal, oligopoly profits, and (b) divert part of those profits to subsidize the higher standard. This dynamic was particularly important in the oligopoly market for fish sticks and other processed seafood made from socalled "whitefish" species. Unilever's purchashing power in this market gave it enormous leverage over suppliers. By 2006, MSC standards covered one-third (32\%) of the world's whitefish production, ${ }^{82}$ and whitefish accounted for roughly three-quarters of all MSC-certified seafood. ${ }^{83}$ Big fisheries similarly saw certification as a way of encouraging consumers to switch to new fish stocks including New Zealand hoki, South African plaice, and Australian lobsters. ${ }^{84}$

Unilever's used its power shrewdly for maximum effect. Its immediate demands were limited to insisting that its one hundred or so long-term fish suppliers comply with local law and provide evidence that they were "progressing" toward sustainability. ${ }^{85}$ By comparison, its long-term goals depended on creating a competition to see which suppliers could introduce sustainability the fastest. Unilever did this

obtaining a Clean Air Act permit from the U.S. EPA can cost up to $\$ 125,120$ and take ten years. Editorial, The 'Absurd Results' Power Grab, WALL ST. J. (Feb. 24, 2014).

80. Price premiums vary dramatically from species to species and are almost certainly strongest for specialty fish like salmon. Howes, supra note 75 , at 87 . Recent evidence suggests that pollock can also earn a premium in some markets. Cathy A. Roheim, Frank Asche \& Julie Insignares Santos, The Elusive Price Premium for Ecolabelled Products: Evidence from Seafood in the UK Market, 62 J. AGRIC. ECON. 655, 655-68 (2011) (reporting 14.2\% premium in politically-correct London).

81. ConRoy, supra note 45 , at 216.

82. $I d$. The corresponding figure for non-whitefish was just six percent. $I d$.

83. Id.

84. UNILEVER CorP., supra note 78, at 10 . Other fisheries tried to block this strategy by certifying established species. Graeme Auld et al., Can Non-State Governance "Ratchet Up" Global Standards? Assessing their Indirect Effects and Evolutionary Potential (prepared for the 2009 Am. Political Sci. Ass'n Annual Meeting), available at http://papers.ssrn.com/sol3/papers. cfm?abstract_id=1450435 (Alaskan and Canadian salmon).

85. UNILEver CoRP., supra note 78, at 4,6. Unilever increased this pressure in 1998 by promising to terminate any supplier that failed all five of its in-house sustainability criteria. Id. at 6 . By December 2002, Unilever bought "the bulk" of its fish from suppliers that the company's inhouse assessment tool rated "sustainable or well managed." Id. at 6,8 . 
by, inter alia, announcing a purchasing preference for MSC-certified seafood; pressuring long-term suppliers to certify; ${ }^{86}$ and setting target dates for transitioning the company to $100 \%$ sustainable products. ${ }^{87}$ By 2006, MSC had certified many of Unilever's biggest suppliers. ${ }^{88}$

Unilever's efforts were further amplified when retail oligopolists like Sainsbury and Walmart ${ }^{89}$ suddenly found it easier to offer sustainable fish and promptly deployed sustainability as a weapon to defend and expand their market shares. This pressure was further amplified by economies of scale on the supply side as fishermen, wholesalers, processors, and distributors found it cheaper to adopt the new standard for all purposes than to maintain redundant facilities for un-certified fish. ${ }^{90}$

Politics. MSC's fifteen-member Board exercises nearly complete control over the documents that define certification, ${ }^{91}$ the companies that are allowed to perform certifications, and the fisheries that are

86. Id. at 4 (Unilever promised to "work closely" with suppliers to change fish stock management and fisheries practices); Jim Gilmore, Case Study 3: MSC Certification of the Alaska Pollock Fishery, in SEAFOOD ECOLABELling, supra note 77, at 270 (describing Unilever discussions with Alaska pollock fishery: "At the time, Unilever was one of the largest, if not the largest, whitefish buyer in the world" and bought a large fraction of its needs from the Alaskan market.).

87. Rupert Howes, supra note 75, at 81, 95 (describing Walmart's 2006 promise to purchase all wild-caught seafood from MSC-certified sources within five years); Id. at 95 (describing Marks \& Spencer's 2007 announcement that it would source all wild fish from certified sources by 2012); Unilever CORP., supra note 78, at 4 (describing Unilever's 1996 promise to source all fish from sustainable stocks by 2005); Alexia Cummins, The Marine Stewardship Council: A Multi-Stakeholder Approach to Sustainable Fishing, 11 CoRp. Soc. Resp. \& EnVTL. MgmT. 85, 92-93 (2004) (describing Sainsbury's 2003 promise to source all wild fish from sustainable stocks by 2010); Jason LaChappelle, Landing the Big Fish: 5 Questions with MSC About the McDonald's USA Announcement, ISEAL ALLIANCE (Mar. 19, 2013), http:/www.isealalliance.org/online-community/blogs/landing-the-big-fish-5-questions-with-msc-about-the-mcdonald \%E2\%80\%99s-usa-announcement (describing McDonalds' announcement of MSC-only fish policies in Europe (2011) and U.S. (2013)).

88. Participating fisheries included Unilever's Alaskan Pollock, Chilean hake, South African hake, and New Zealand hoki suppliers. Unilever CoRP., supra note 78, at 4.

89. van der Kloet \& Havinga, supra note 48, at 15 (listing supermarkets, fish restaurants, and seafood retailers that "prefer to sell MSC labeled seafood"); ConRoY, supra note 45, at 219 (Walmart "has notified all its seafood suppliers that it is seeking to purchase only MSC-certified wild-caught fish."); Cummins, supra note 87, at 93 (discussing Sainsbury's commitment to "work with their suppliers" to move toward sustainable fish); Howes, supra note 75 , at 95 (describing Walmart's promise to encourage suppliers to work with WWF and Conservation International to develop sustainable practices); $i d$. at 96 (Many UK retailers have announced a " 'buyer preference' for MSC-certified fish").

90. Howes, supra note 75 , at 95 (predicting that Walmart's decision to favor certified fish would have a "ripple effect . . . across the whole marketplace"); UNILEVER CoRP., supra note 80, at 1 (Unilever gave suppliers "strong encouragement" to adopt suitable practices and work toward certification.). The standard even survived Unilever's 2005 decision to sell its European frozen food business. So far, the new owners have continued to demand MSC-endorsed fish. Conroy, supra note 45 , at 219.

91. Hale, supra note 74 , at 312 . 
certified. ${ }^{92}$ Strikingly, MSC has resisted calls to make the Board more democratic, arguing that this would "paralyse[]"decision-making and force the Board to implement policies "it did not agree" with. ${ }^{93}$

Most MSC politics seems to revolve around the certification of individual fisheries. ${ }^{94}$ While certifications are initially performed by outside companies, final approval comes from the Board. In practice, the Principles allow wide discretion. ${ }^{95}$ Certification companies use this freedom to engineer compromises that limit the total cost to fisheries $^{96}$ while simultaneously demanding enough reforms to satisfy the NGOs. ${ }^{97}$ Not surprisingly, this process is "highly politicized." 98 Fisherman charge that certifiers often make demands less from science than to appease the NGOs. ${ }^{99}$

Groups that fail to get their way routinely threaten to leave MSC. ${ }^{100}$ This leverage is real: If enough NGOs leave, MSC's reputation with consumers will collapse. But if the fisheries leave, MSC will have no fish to certify. Given this balancing act, the Board's real power is probably limited. ${ }^{101}$

Government Interactions. Practically all MSC fisheries are already regulated by governments. This is almost certainly because unregulated fisheries are too competitive to afford certification. ${ }^{102}$ MSC's standards do, however, add an additional layer of regulation which

92. Howes, supra note 75 , at 88 .

93. May et al., supra note 77 , at 33; but see Cummins, supra note 87 , at 89-90.

94. The Board also manages amendments to the "Principles."

95. Certifiers must choose 80-100 unique "performance indicators" for each fishery. Cummins, supra note 87 , at 87 . Even then, fishery science leaves room for a wide range of opinions. May et al., supra note 77, at 20 ("[T]here is a huge diversity of strong opinions around as to what is an acceptable consequence of fishing. Not all of these opinions are free from self-interest.").

96. Fisheries typically interview several certification companies before selecting one. The interviews feature detailed discussions about what reforms will be needed, the chances of successful certification, and expected fees. Howes, supra note 75 , at 88 . The fact that fisheries tend to make the biggest upgrades after preassessment but before certification suggests that certifiers honor these promises. Id.

97. Gilmore, supra note 86 , at 278 .

98. Cummins, supra note 87 , at 88 .

99. Certifiers may have deliberately manipulated scores so that they could order "additional, time-consuming steps to placate" NGOs. Gilmore, supra note 86, at 277.

100. May et al., supra note 77 , at 24 ("Every certification to date has been subject to comments typified by 'We support certification but not for this fishery' and 'If this fishery is not certified then the MSC is doomed.'").

101. To the extent that any discretion remains, board members presumably decide based on their norms, ethics, and and ideology.

102. MSC certification has worked poorly in fisheries that lack quotas or operate in unregulated waters. Lars H. Gulbrandsen, The Emergence and Effectiveness of the Marine Stewardship Council, 33 MARINe POL'y 654, 658 (2009). 
lets foreign governments and NGOs influence fisheries ${ }^{103}$ subject to pushback from local officials. ${ }^{104}$

Results. By 2012, MSC had certified more than one hundred fisheries and another hundred were undergoing assessment. ${ }^{105}$ This gave MSC power over extensive resources including Alaskan pollock (onethird of total U.S. seafood production) ${ }^{106}$ and hake (South Africa's most valuable fishery). ${ }^{107}$ The extent to which MSC has actually used this power to improve fishery practices is less clear, especially since most fisheries seeking certification have high standards already. ${ }^{108}$ Despite this, certification has probably produced modest increases in sustainability. ${ }^{109}$ Meanwhile, certification remains confined to fisheries in the developed world ${ }^{110}$ with almost no penetration of the Asian markets that consume two-thirds of the world's seafood.111 MSC's stated goal of becoming a universal fishing standard is unlikely to happen any time soon.

\section{E. A Private Legislature: Coffee}

MSC tried and failed to suppress politics. But if politics cannot be eliminated, it should at least be domesticated. The coffee industry has

103. In 2005, the Nordic countries urged the UN's Food and Agricultural Organization to create its own non-binding labeling scheme. MSC restructured itself to help implement the system. Id. at 655; see also Food \& Agric. Org. of The United Nations, Guidelines for the Ecolabelling of Fish and Fishery Products From Marine Capture FISHERIES 131-50 (2009).

104. May et al., supra note 77, at 24 (describing U.S. federal fishery managers' anger at "overly critical assessment report" and how MSC "sought an audience to calm the waters").

105. List of All Certified Fisheries, MSC, http://www.msc.org/track-a-fishery/fisheries-in-theprogram/certified/all-certified-fisheries (last visited May 21, 2014).

106. Howes, supra note 75, at 85; UNILEVER CORP., supra note 78 , at 11.

107. Unilever Corp., supra note 78, at 11.

108. Gilmore, supra note 86, at 277 ("Pollock was already one of the world's best fisheries, and indeed this is why it chose to apply for MSC"). There is also evidence that joining MSC discourages post-certification reforms. Simon R. Bush, Hilde Toonen, Peter Oosterveer \& Arthur P.J. Mol, The 'Devils Triangle' of MSC Certification: Balancing Credibility, Accessibility and Continuous Improvement, 37 MARINe Policy 288, 289 (2012) (WWF refused to license its panda logo to fishermen who claimed to follow higher standards than MSC.); Gilmore, supra note 86, at 272 (Alaska Pollock fisheries pursued MSC certification as a hedge against NGO and U.S. government pressure.); Trevor J. Ward, Measuring the Success of Seafood Ecolabelling, in SEAFOOD ECOLABELLING, supra note 75, at 217-18 (Australian fishermen cited MFC approval as evidence that further reforms were unnecessary.).

109. Hale, supra note 74, at 312-13; Howes, supra note 75, at 94 (MSC reforms in South Georgia Chilean sea bass fishery included putting "independent observers on each boat, closing the fishing grounds for half of the year and requiring lines to be set at night to reduce bird bycatch.").

110. Gulbrandsen, supra note 102 , at 658 .

111. Hale, supra note 74 , at 313 . As of 2010 , MSC had certified just three developing world fisheries. Id. 
developed elaborate insititutions to make private politics fairer and more predictable.

History. U.S. diplomats organized coffee cartels to maintain Latin America's political stability throughout World War II and the Cold War. ${ }^{112}$ However, the agreements quickly collapsed after the fall of Communism in 1989. Coffee prices fell forty percent over the next five years and have remained volatile ever since. ${ }^{113}$ The crisis impoverished farmers, suppressed investment, and threatened the long-run viability of coffee supplies. ${ }^{114}$

NGOs organized various labeling initiatives to address the crisis in 1995-1997.115 However, all of these standards focused on the ten percent or so of suppliers who sell to specialty stores like Starbucks. ${ }^{116}$ This was the only segment of the market where consumers are willing to pay a premium for sustainability. ${ }^{117}$

By the early 2000s, a second "coffee crisis" was in the offing and producer income had fallen to a thirty-year low. ${ }^{118}$ The German Federal Ministry for Economic Cooperation and Development (DMZ) ${ }^{119}$ responded by organizing discussions with industry and NGOs in $2001 .{ }^{120}$ This led to proposals for a mainstream standard that would cover the coffee sold in supermarkets, restaurants, and institutions..$^{121}$

112. Int'l Coffee Org., The International Coffee Organization 1963-2013: 50 Years Serving the World Coffee Community 3 (2013). European governments joined the scheme in $1962 . I d$. at 39.

113. Id. at 13.

114. Petra Kuenkel et al., Partnerships for Sustainability Case Study The Common Code for the Coffee Community (4C) (June 26, 2008) (draft for the National Acadamies Policy and Global Affairs Division), available at http:/www.nap.edu/openbook.php?record_id=12541\& page $=85$. Large coffee companies also worried that volatile prices would encourage rich nation consumers to try new beverages. Id.

115. The main examples were Fairtrade, Organic, Rainforest Alliance, and Utz Certified. Graeme Auld et al., Can Technological Innovations Improve Private Regulation in the Global Economy?, Bus. \& Pol., Oct. 2010, at 13-14; Ans Kolk, Mainstreaming Sustainable Coffee, 21 Sustainable Dev. 324, 325 (2013).

116. 4C Ass'N, ANNuAl REPORT 5 (2007), available at http://www.4c-coffeeassociation.org/ uploads/media/4C_Annual_Report_2007.pdf.

117. Starbucks successfully introduced Fair Trade Certified coffee despite higher prices. CoNROY, supra note 45 , at 2.

118. 4C Ass'N, ANnUAl RePORT 1 (2010), available at http://www.4c-coffeeassociation.org/up loads/media/4C_AnnualReport2010_web_en.pdf?PHPSESSID=9edcsuk5rqnne8e85lk95v1cn3; Kuenkel et al., supra note 114.

119. Deutsche Gesellschaft für Technische Zusammenarbeit.

120. Much of the actual work was done by the German Government's Bundesministerium für Wirtschaftliche Zusammenarbeit und Entwicklung (BMZ) as implementation body. 4C Ass'N supra note 116, at 4. I ignore this distinction in what follows.

121. See Kuenkel et al., supra note 114. 
Goals included raising green coffee prices, ${ }^{122}$ reducing the risk of scandal, ${ }^{123}$ and eliminating overlapping certification requirements. ${ }^{124}$

The fact that the talks included Kraft, Nestle, Sara Lee, and Tschibo-which collectively accounted for forty percent of all worldwide sales ${ }^{125}$ - gave the project significant leverage over suppliers. At the same time, only one in twenty customers was prepared to switch brands over social or environmental issues, even when prices stayed constant. ${ }^{126}$ Furthermore, most of these consumers were located in Europe, which accounts for just thirty percent of the worldwide purchases. ${ }^{127}$

By mid-2002, the discussions had expanded to include several large supplier organizations and NGOs. ${ }^{128}$ In January 2003, the German Coffee Association (DKV) partnered with $\mathrm{BMZ}^{129}$ to pursue agreement around a "Common Code for the Coffee Community" that would set baseline standards for suppliers. ${ }^{130}$ Despite widespread skepticism, most of the thirty-five big coffee companies, producers, and NGOs invited to the kickoff meeting agreed to join a Steering Committee. ${ }^{131}$ Drafting proceeded by consensus, ${ }^{132}$ forcing dissenters

122. Id.

123. Marianne Beisheim \& Christopher Kaan, Transnational Standard-Setting Partnerships in the Field of Social Rights:The Interplay of Legitimacy, Institutional Designs, and Process Management, in Democracy and Public-Private Partnerships in Global Governance 122, 131-32 (Magdalena Bexell \& Ulrika Mörth eds., 2010) (Large companies worried that their "credibility ... would be put at risk if, for example, one of their suppliers . . did not comply.").

124. Standard Setting Organizations, 4C Ass'N, http://www.4c-coffeeassociation.org/become-amember/membership-benefits/standard-setting-organizations.html\#2 (last visited May 21, 2014) ("More and more producer organizations, companies and development agencies in the coffee sector are requesting that standard setting organizations cooperate to avoid duplication of efforts."); Ans Kolk, Towards a Sustainable Coffee Market: Paradoxes Faced by a Multinational Company, 19 Corp. Soc. Resp. Envtl. Mgmt., 79, 82 (2012); 4C Ass'N, supra note 118 at 4 (Compatible standards let companies blend coffee from different sources to achieve whatever average sustainability level best fit their marketing needs).

125. As of 2005, Nestle and Kraft each had a $13 \%$ share of the market. Sara Lee and Dowe Egberts each had $10 \%$ shares while Proctor \& Gamble had a $4 \%$ share. Ans Kolk, Corporate Social Responsibility in the Coffee Sector: The Dynamics of MNC Responses and Code Development, 23 Eur. MGMT. J. 228, 229 (2005).

126. Kolk, supra note 124 , at 81 .

127. Kolk, supra note 115 , at 334 .

128. Kuenkel et al., supra note 114. The world's fifth biggest roaster, U.S.-based Smuckers, never joined. Smuckers accounts for roughly one-tenth of worldwide green coffee purchases. Specialty outlets operating their own in-house standards also declined to join. Kolk, supra note 115 , at 333

129. Kuenkel et al., supra note 114. The German Coffee Association (DKV) and German governmment (BMZ) each contributed $€ 500,000$ to the project.

130. Id.

131. Founding members included Kraft, Sara Lee, Tschibo, Nestle, Oxfam, Rainforest Alliance, Utz Kapeh, the Flanders International Cooperation Agency, and the German Ministry for 
to choose between agreeing and walking away. The Code was announced in September 2004. ${ }^{133}$

The project was renewed and expanded in 2005.134 This second phase focused on negotiating a constitution that would create a new body ("4C") to administer the Code. ${ }^{135}$ Once again, drafting proceeded by consensus. ${ }^{136}$ Suppliers were suspicious of the big roasters and only joined after being promised more votes than any other group. ${ }^{137}$ Final agreement came through a series of "We'll join if you'll join" negotiations in late 2006. ${ }^{138}$ In April 2007, a "Who's Who" of seventy-one European Coffee manufacturers, trade associations, and producer organizations met for 4C's First General Assembly where they voted to adopt by-laws and elect a governing council. ${ }^{139}$

The first $4 \mathrm{C}$ coffee went on sale in October 2007.140 By 2010, about $8 \%$ of all coffee exports belonged to $4 \mathrm{C}$ or an affiliated standard. ${ }^{141}$ However, demand failed to keep up. By 2009 , the supply of $4 \mathrm{C}$ coffee was twenty times larger than actual purchases, ${ }^{142}$ and $4 \mathrm{C}$ coffee prices were the same as uncertified coffee. ${ }^{143}$ Although $4 \mathrm{C}$ mounted initiatives to fix the problem, ${ }^{144}$ supply was still more than twice actual

Technical Cooperation. Organizers continued to recruit new Steering Committee members throughout the negotiations. For a complete list see Kuenkel et al., supra note 114.

132. Id.

133. Id.

134. Id. (New partners included The European Coffee Federation, the British Development Corporation, and the Swiss State Secretariat for Foreign Affairs). The European Coffee Federation, BMZ, and the Swiss State Secretariat for Economic Affairs each provided $€ 500,000$ to finance the project. Kuenkel et al., supra note 114. Additional sums were donated by the Flanders International Cooperation Agency. 4C Ass's, supra note 116, at 22.

135. Kuenkel et al., supra note 114; 4C Ass's, supra note 116, at 4.

136. Kuenkel et al., supra note 114.

137. $l d$.

138. 4C Ass'N, supra note 116, at 2-4; Auld et al., supra note 115, at 13-14; Kuenkel et al., supra note 114.

139. 4C Ass'N, supra note 116, at 2, 6 .

140. Id. at 2; Kuenkel et al., supra note 114.

141. 4C Ass' s, supra note 118, at 4; 4C Ass'N, supra note 116, at 12; Graeme Auld, Assessing Certification as Governance: Effects and Broader Consequences for Coffee, 19 J. ENv'T \& DEv. $216,220(2010)$ (4C certifies $6 \%$ of world crop; the next largest standards are IFOAM (1.2\%) and Fair Trade $(0.9 \%)$.).

142. 4C Ass'N, ANNUAL Report 25 (2009), available at http://www.4c-coffeeassociation.org/ uploads/media/4C_AnnualReport2009_web_lr_en.pdf. The situation was only slightly better for specialty coffees. In 2006, Fairtrade producers sold just $10-20 \%$ of their output as certified; the rest was sold at regular market prices. Kolk, supra note 115, at 329 n.2. See also, Kolk, supra note 125 .

143. See Kolk, supra note 125.

144. 4C Ass'N, supra note 142, at 7 ("The Strategic Plan 2015 defines clear activities and measures to better balance supply and demand in the medium-term"). 
purchases in 2010 and $2011 .{ }^{145} 4 \mathrm{C}$ announced that it was reorganizing itself around a new, demand-oriented business plan in 2011.146

Institutions. 4C's General Assembly includes all of the organization's members and is divided into separate chambers for producers, industry, and NGOs. Each chamber must separately approve all major policy initiatives including amendments to the $4 \mathrm{C}$ Code. ${ }^{147}$ The Assembly also elects a Governing Council composed of seven producers, five industry representatives, and five NGOs. ${ }^{148}$ The Council is responsible for policy direction. ${ }^{149}$ A professional staff ("Project Secretariat") ${ }^{150}$ generates documents, schedules meetings, and hires experts. ${ }^{151}$ It focuses on overcoming frictions so that $4 \mathrm{C}$ members can reach agreement but refuses to take sides on substance.

As in our food example, the big processors have given suppliers and NGOs an equal voice in designing the $4 \mathrm{G}$ standard. In return, suppliers have provided ideas for making the standard more cost-effective ${ }^{152}$ while NGO participation has helped to insulate $4 \mathrm{C}$ from criticism. ${ }^{153}$

Politics. All 4C members support higher prices for green coffee. ${ }^{154}$ Unlike suppliers and NGOs, however, the big coffee manufacturers insist that any "major price increases" be matched by quality increases. ${ }^{155}$ This probably reflects concerns that producers could de-

145. Supply stood at $14 \%$ while demand was just $6 \%$, of which $4 \mathrm{C}$ supplied just $2 \%$. Kolk, supra note 115 , at $329-30$. The supply figure is only a "guesstimate" and the true figure may be lower. $I d$.

146. 4C Ass'N, supra note 118, at 1, 2 (4C was reorganized around a new "demand driven" business model in February 2011); 4C Ass'n, AnNual Report 5 (2008), available at http:/www. 4c-coffeeassociation.org/uploads/media/4C-Annual-Report-2008_en_lr.pdf (4C's roaster members committed to buying more coffee from verified producers over time and reporting purchases annually.).

147. Kuenkel et al., supra note 114.

148. 4C Ass'N, supra note 118, at 6; Kuenkel et al., supra note 114.

149. 4C Ass's, supra note 142, at 8.

150. Kuenkel et al., supra note 114 .

151. Id.

152. Kuenkel et al., supra note 114 ("Many standards so far, have been developed by experts with little or no input from those who are intended to comply with the standards.").

153. Id. NGOs worried that working with business would offend their constituencies or undermine demand for existing specialty coffee standards. Id.

154. 4C Ass'N, supra note 146, at 10 (Producer demand for higher prices); Kolk, supra note 125 (Big corporations agreed on the need for high, stable green coffee prices); Kuenkel et al., supra note 114 (Government saw 4C as a replacement for Cold-War era price agreements and a way for private money to improve production, "a role that national governments often did not provide"). The parties also agreed on various subsidiary goals, including initiatives to reduce duplication in existing standards and provide direct services for improving suppliers' production methods. 4C Ass'N, supra note 146, at 10; Kuenkel et al., supra note 114.

155. Kolk, supra note 124 , at 84 (Statements by strongly pro-standards roaster Sara Lee). 
cide to pocket higher profits without investing in better infrastructure, working conditions, and environmental practices. ${ }^{156}$

As in our fishing example, the negotiations that produced 4C's Code and governance documents featured "many conflicts" with "almost every stakeholder group threatening to leave . . . at some point." 157 This ultimately resulted in an implicit bargain whereby suppliers that invested in improved practices would receive higher prices from roasters. ${ }^{158}$ The problem, so far, is that the big European roasters have failed to deliver. As of 2012, 4C members only filled about six percent of their needs with $4 \mathrm{C}$ or $4 \mathrm{C}$-compatible coffee. ${ }^{159}$ Instead of receiving higher coffee prices, suppliers ended up making the requested improvements at their own expense-the direct opposite of the intended bargain.

Interactions with Government. Organizers originally wanted to launch $4 \mathrm{C}$ as a public body but were blocked by producer nations. ${ }^{160}$ Since then, officials have taken a neutral position, ${ }^{161}$ trusting in $4 \mathrm{C}$ members' self-interest to raise prices and improve infrastructure. $4 \mathrm{C}$ continues to work closely with the ICO. ${ }^{162}$

Results. The current 4C Steering Committee members plus their de facto ally Sara Lee ${ }^{163}$ buy roughly $80 \%$ of all certified coffee purchased worldwide. ${ }^{164}$ This economic muscle allowed $4 \mathrm{C}$ to set working conditions for hundreds of thousands of workers around the

156. Id. Company attitudes also depended on the countries where they operated. Kolk, supra note 115, at 327. Many multinationals prefer a low standard that lets them market differently in different countries. Kolk, supra note 124, at 79-89.

157. Id. (describing negotiations that led to $4 \mathrm{C}$ 's Code and governance documents). Individual threats came from Oxfam, Greenpeace, and Food First Informations-und-Aktions-Netzwork. Id. Greenpeace and Food First subsequently carried out their threats. Id.

158. Kuenkel et al., supra note 114; see also 4C Ass'N, supra note 142, at 5 (4C's roaster members commit to buying increasing amounts of coffee from verified producers over time and reporting their purchases annually).

159. In 2008, Starbucks purchased $77 \%$ of its needs from certified sources. Among mainstream companies, Tschibo was the highest at $6.2 \%$. Kolk, supra note 115 , at 332 .

160. Kuenkel et al., supra note 114 (describing early plans to house $4 \mathrm{C}$ within the ICO); Auld, supra note 141 , at 221 .

161. Government staff seconded to the $4 \mathrm{C}$ Secretariat were told to pursue whatever areas of agreement existed while maintaining a neutral position on content. See Kuenkel et al., supra note 114; see also Beisheim \& Kaan, supra note 125.

162. Auld et al., supra note 84; Auld, supra note 141, at 229 . (4C "has been engaged in dialogue with ICO to determine what role it might play in implementing the 2007 ICA"); Kuenkel et al., supra note 114 (4C Board includes an ICO representative).

163. Sara Lee left $4 \mathrm{C}$ in 2008 but remains a de facto ally through its close association with the 4C-compatible Utz Kapeh standard.

164. Kolk, supra note 124 , at 84 (Table $2 ; 78-82 \%$ estimate). 
world. ${ }^{165}$ This includes requiring producers to immediately ban ten "Unacceptable Practices" and make steady improvements on an additional twenty-eight "noncompliance with sustainability" issues. ${ }^{166}$

Despite these achievements, only about ten percent of the world's suppliers have so-far adopted $4 \mathrm{C}$ or a $4 \mathrm{C}$-compatible standard. ${ }^{167}$ The basic problem is that the big coffee companies do not buy nearly enough certified coffee. Indeed, compliance could even decline since it is hard to see why producers should go on supporting a standard that earns no revenue. One obvious solution would be for $4 \mathrm{C}$ to develop a new and more stringent standard. This would simultaneously reduce the current over-production of $4 \mathrm{C}$ coffee while increasing consumer demand.

\section{F. Politics as Standards War: Forestry}

We have seen that private politics often includes walkout threats. To be credible, these must occasionally be carried out. This opens the door to multiple competing standards. Private forestry standards have followed this pattern since the 1990s.

History. Tropical deforestation became a prominent issue in the 1980s. ${ }^{168}$ But while rich nation diplomats were able to build consensus around "sustainable forestry," efforts to implement the concept as an enforceable treaty collapsed in $1992 .{ }^{169}$ At this point, the World Wildlife Fund persuaded NGOs, small timber producers, and high-end furnituremakers to organize a private standard. ${ }^{170}$ The new Forest

165. 4C Ass'N, supra note 142, at 2 (stating that $4 \mathrm{C}$ standards set working conditions for 240,000 workers in twenty countries.)

166. 4C Ass's, supra note 142, at 6; Standard Setting Organizations, supra note 127.

167. This success is partly due to low certification costs: Unlike MSC, $4 C$ pays for verification and programs that teach farmers how to improve their methods. Kuenkel et al., supra note 114; Auld, supra note 141, at 221.

168. David Humphreys, Forest Politics: The Evolution of International CooperaTION 1 (1996).

169. Auld et al., supra note 115, at 11; Steven Bernstein \& Benjamin Cashore, Nonstate Global Governance: Is Forest Certification a Legitimate Alternative to a Global Forest Convention?, in Hard Choices, Soft Law: Voluntary Standards in Global Trade, EnvironMent, AND Social Governance 33, 47 (John J. Kirton \& Michael J. Trebilcock eds., 2004); Errol Meidinger, The Administrative Law of Global Private-Public Regulation: the Case of Forestry, 17 EuR. J. INT'L L. 47, 50 (2006).

170. Meidinger, supra note 169, at 51. Other players included The Woodworkers Alliance for Rain Forest Protection, the Rain Forest Alliance, and British do-it-yourself retailer B\&Q. See generally Graeme Auld et al., Perspectives on Forest Certification: A Survey Examining Differences Among the US Forest Sectors' Views of their Forest Certification Alternatives, in FOREST Policy for Private Forestry 271, 272 (L. D. Teeter, Ben Cashore, \& D. Zhang, eds., 2002); Conroy, supra note 45, at 244; Its Global, Forest Certification - Sustainability, Gov. ERNANCE, AND RISK 21 (2011), available at http://www.itsglobal.net/sites/default/files/itsglobal/ 
Stewardship Council (FSC) interpreted the official consensus liberally to include ambitious biodiversity, ecology, and social justice goals. ${ }^{171}$

FSC saw private enterprise as obstructionist and adopted governance rules that deliberately reduced business members' ability to influence policy. ${ }^{172}$ Instead, it hoped that activist pressure would persuade big retailers to demand FSC compliance from their suppliers. The ensuing campaign included more than 600 demonstrations at Home Depot stores. ${ }^{173}$ Home Depot resolved the dispute in 1999 by agreeing to terminate vendors who violated local law ${ }^{174}$ and promising to end purchases from endangered regions by 2003. ${ }^{175}$ It also encouraged its suppliers to compete on sustainability. Specific tactics included announcing a purchasing preference for FSC when price and quality are similar, ${ }^{176}$ pressing suppliers to adopt FSC, ${ }^{177}$ and adopting a long term "intention" to purchase all wood products "following rules that only FSC currently meets." 178 Similar concessions were promptly adopted by home improvement chains across the U.S. and Europe. ${ }^{179}$ This persuaded many suppliers that it was cheaper to adopt FSC for all purposes than to maintain redundant systems. ${ }^{180}$ In-

Forestry\%20Certification-Sustainability \%20Governance \%20and\%20Risk \%20\%282011\%29.pdf [hereinafter Forest CERTIFICATION].

171. Forest Stewardship COUNCIL, FSC INTERNATIONAL STANDARD: FSC PRINCIPLES AND CRITERIA FOR FOREST STEWARDSHIP 7 (2012), available at https://ic.fsc.org/download.fsc-std-01001-v5-0-revised-principles-and-criteria-for-forest-stewardship.a-1780.pdf [hereinafter FSC INTERNATIONAL]; Meidinger, supra note 169, at 79 (describing FSC's "expansive vision" of a "just forest").

172. See, e.g., Auld et al., supra note 170 , at 272 (FSC's governance structure was deliberately designed to "eliminat[e] business dominance" over standards); Bernstein \& Cashore, supra note 169 , at 39 (FSC voting is structured so that business occupies a permanent minority).

173. Erika N. Sasser, Gaining Leverage: NGO Influence on Certification Institutions in the Forest Products Sector, in Forest Policy for Private Forestry 229, 240 (L. D. Teeter, Ben Cashore, \& D Zhang, eds., 2002).

174. Wood Purchasing Policy, Home Depot, https://corporate.homedepot.com/CorporateResponsibility/Environment/WoodPurchasing/Pages/default.aspx (last visited May 22, 2014).

175. Frequently Asked Questions, НОME DEPOT, https://corporate.homedepot.com/Corporate Responsibility/Environment/WoodPurchasing/Pages/FAQs.aspx (last visited May 22, 2014); Press Release, Home Depot, The Home Depot Introduces Eco Options (Apr. 17, 2010), available at http://www.newswire.ca/en/story/84479/the-home-depot-introduces-eco-options.

176. Meidinger, supra note 169, at 57-8; Frequently Asked Questions, supra note 178; Wood Purchasing Policy, supra note 177 (promising "preferential treatment" for certified products and companies that practice responsible forestry).

177. Frequently Asked Questions, supra note 175; Wood Purchasing Policy, supra note 177; Meidinger, supra note 169, at 58; Press Release, supra note 175.

178. Auld et al., supra note 170 , at 273.

179. Meidinger, supra note 169, at 58 (Lowes in the U.S.; Homebase, B\&Q, Sainsbury in the UK; Kingfisher in Europe and Asia); Bernstein \& Cashmore, supra note 169, at 51 (describing initial FSC support from "B\&Q, Sainsbury, Centex, and German publishing comparies").

180. Alan Purbawiytna \& Markku Simula, Int'l Tropical Timber Org., Developing Forest Certification: Towards Increasing the Comparability and acceptance of 
dividual players in the homebuilding, publishing, and furnituremaking also adopted the standard. ${ }^{181}$ Altogether, roughly one-fourth of the U.S. market seems to have expressed a purchasing preference for FSC. ${ }^{182}$

The suppliers fought back by creating their own Sustainable Forests Initiative (SFI) in 1994. ${ }^{183}$ Unlike FSC, SFI interprets the "sustainable forestry" concept in a way that lets members adjust their goals to local conditions. ${ }^{184}$ This does not make the standard trivial: At least fifteen members resigned from the American Forest \& Paper Association rather than adopt the standard. ${ }^{185}$ By 1999 SFI included more than $85 \%$ of U.S. paper production. ${ }^{186}$ It also covered more than $90 \%$ of the forests owned by large timber companies, although the "vast majority" of privately owned forests remain uncertified. ${ }^{187}$

In 1999, small European suppliers organized a Pan-European Forest Certification Council (PEFC) to recognize each others' standards. ${ }^{188}$ They, too, argued that sustainability goals should depend on local con-

Forest Certification Systems WORLDWIDE 83 (Stocking different certification standards "is costly and sometimes physically impossible due to a lack of space"); see also Mayer \& Gereffi, supra note 15, at 9-10 (Adopting uniform standards reduces social costs); ConRoY, supra note 45, at 244 (describing Anderson Windows' decision to adopt FSC).

181. See Bernstein \& Cashmore, supra note 169 , at 51 (naming German publishing companies that adopted FSC's standards); Sasser, supra note 173, at 237 (naming selected U.S. and Netherland publishers that adopted FSC's standards); PURBawiYatNa \& SimULA, supra note 180, at 80 (noting that Kingfisher, IKEA, WalMart, and Home Depot all require their suppliers to provide FSC or equivalently certified products).

182. Sasser, supra note 173 , at 241.

183. See Meidinger, supra note 169, at 54; Peter Sprang \& Nils Meyer-Ohlendorf, Ecologic, Public Procurement and forest Certification: Assessment of the Implications for Policy, Law and International Trade 12 (2006) (SFI was founded and became operational in 1995). The standard was originally written as a public relations exercise. Meidinger, supra note 169, at 67-68 (Staff members drafted initial standard in consultation with member companies and focus groups).

184. Scott Berg \& Rick Cantrell, Sustainable Forestry Initiative: Toward a Higher Standard, 97 J. FORESTRY 33, 34-35 (1999) (SFI "is the US forest and paper industry's response to the challenge of working toward the goal of sustainable forest management articulated at the United Nations Conference on Environment and Development (UNCED) Earth Summit in 1992."). See SPRANG \& MeYer-Ohlendorf, supra note 183, at 13-15 (providing a comparison of the FSC and SFI).

185. Berg \& Cantrell, supra note 184 , at 33 (" 15 forest products companies were asked to leave the association ...."); Roger Brown \& Daowei Zhang, The Sustainable Forestry Initiative's Impact on Stumpage Markets in the US South, 35 CAN. J. For. REs. 2056, 2056 (2005) ("The AF\&PA has asked as many as 17 forest product companies not to renew their membership ...."); Conroy, supra note 45 , at 244 (" 10 of [the trade association's] 250 members withdrew from the association immediately and another 15 were dismissed . ...").

186. Brown \& Zhang, supra note 185, at 2056.

187. Id. at 2056-57; Wortman, supra note 76.

188. Forest Certification, supra note 170 , at 5, 11. 
ditions ${ }^{189}$ and be affordable for small forests. ${ }^{190}$ PEFC endorsed its first national scheme in $2000^{191}$ and began certifying non-European forests in 2003.192 SFI joined in 2005.193 By then, PEFC standards covered nearly twice as much acreage as FSC. ${ }^{194}$ Many retailers began purchasing wood interchangeably from FSC and PEFC. ${ }^{195}$

Politics. FSC and the PEFC are both governed by General Assemblies ${ }^{196}$ that approve all changes to basic documents and policy. ${ }^{197}$ However, the memberships are different. Most PEFC members are national standard-setting bodies created by long-established forestry associations. This creates a rough equality so that PEFC is able to operate on a one country, one vote basis. ${ }^{198}$

By comparison, FSC is open to any individual or group that subscribes to the organization's goals. This makes a one member, one vote principle hard to justify. Instead, FSC follows a corporatist model in which action must be separately approved by economic, social, and environmental sub-chambers. ${ }^{99}$ These are further subdivided by North and South so that there are six bodies in all. ${ }^{200}$ The sub-chambers, in turn, act by "consensus," which is defined to include "the absence of sustained opposition" over "substantial issues" by

189. Id. at 11.

190. Id.; see also What Makes PEFC Unique, PEFC UK LIMITED, http://pefc.co.uk/about-pefc/ what-makes-pefc-unique (last visited May 22, 2014) (PEFC "is tailored to the specific needs of family-and community-owned forests" which lack the economies of scale to finance FSC certification).

191. Forest Certification, supra note 170 , at 11.

192. Meidinger, supra note 169 , at 56 . PEFC has since re-branded itself as "The Programme for the Endorsement of Forest Certification." It currently endorses standards in 30 countries. Ingrid J. Visseren-Hamakers \& Pieter Glasbergen, Partnerships in Forest Governance, 17 Global Envtl. Change 408, 411-12 (2006); About PEFC UK, PEFC UK Limited, http:// pefc.co.uk/about-pefc/about-pefc-uk (last visited May 22, 2014).

193. SFI Inc. - International Acceptance Through PEFC, Sustainable Forestry INITIATIVE 1 (2009), available at http://www.sfiprogram.org/files/pdf/pefc-international-2009-02pdf.

194. Friederike Mechel et al., Public Procurement and Forest Certification: AsSessing the Implications for Policy, Law and International Trade, 41-42 (2006), available at $\mathrm{http}: / / \mathrm{www} . e c o l o g i c . e u /$ sites/files/project/2013/933_final_report.pdf.

195. Bernstein \& Cashore, supra note 169 , at 40.

196. Forest Certification, supra note 170, at 12, 20; see e.g., FSC General Assembly, FSC, http://www.ga.fsc.org/generalassembly.html (last visited May 22, 2014); see also, Meidinger, supra note 169, at 53-54. Approximately two-thirds of the members are organizations; the rest are individuals. Meidinger, supra note 169 , at 54 .

197. Tony Rotherham, Forest Management Certifictation Around the World - Progress and Problems, 87 Forestry Chron. 603, 605; FSC International, supra note 171, at 5.

198. See, e.g., Forest Certification, supra note 170, at 12, 20; Meidinger, supra note 169, at 54.

199. Forest Certification, supra note 170, at 12, 20; see also Meidinger, supra note 169 , at 54. Business originally possessed fewer votes and board members than other chambers. Id. at 53 \& n.30.

200. Meidinger, supra note 169 , at 53 . 
"any important part" of "the concerned interests."201 As a practical matter, the meaning of "consensus" is set by the need to keep dozens of competing interest groups within FSC's coalition. ${ }^{202}$ FSC's recent decision to approve new Principles based on a $75 \%$ majority illustrates how the rule works in practice. ${ }^{203}$

FSC uses ad hoc groups to turn its Principles into specific national and regional standards. ${ }^{204}$ At least half of each national group must be drawn from FSC members "in a balanced way." 205 Like FSC itself, the groups depend on "consensus." As a practical matter, this is defined by members' willingness to walk out on the process. ${ }^{206}$ By comparison, PEFC sees itself as a bottom-up organization. This means that national bodies are free to organize any way they choose and need not reserve places for specific stakeholders. ${ }^{207}$ Despite this, member bodies are sufficiently diverse that their politics frequently revolves around walkout threats. ${ }^{208}$

Standards Wars. The political fights within FSC and PEFC are only half the story. This is because the two standards must also compete with each other to attract consumers and producers. In practice,

201. Id. at 69 . FSC's voting rules codify the consensus principle by guaranteeing that none of the three stakeholder groups can be outvoted. This is qualified by other rules that specify "no chamber shall show sustained opposition." MECHEL ET AL., supra note 194, at 43; cf. VisserenHamakers \& Glasbergen, supra note 192, at 412.

202. These interest groups include: NGOs, indigenous people, and unions in the social chamber; NGOs and academic institutions in the environmental chamber; and trade associations, private forest owners, employees, certification bodies, and consultants in the economic chamber. See Purbawiyatna \& Simula, supra note 180, at 43

203. FSC INTERNATIONAL, supra note 171 , at 3.

204. Rotherham, supra note 197, at 604 . PEFC is based on mutual recognition by national forest systems that "promote high standards of SFM." Purbawiyatna \& Simula, supra note 180, at 45; United Nations Econ. Comm'n for Eur., Forest Products Annual Market REvIEW 2011-2012 113 (2012), available at http://www.unece.org/fileadmin/DAM/timber/publications/FPAMR_2012.pdf [hereinafter UNECE].

205. Purbawiyatna \& Simula, supra note 180 , at 40 (At least half of each group must be FSC members selected to represent the various chambers "in a balanced way.").

206. See Meidinger, supra note 169 , at 69 . One early FSC working group even approved a standard after all of its industry members had walked out. Id. The incident reportedly caused "consternation" and a new "understanding" that industry acceptance of standards "is expected." Id.

207. Forest Certification, supra note 170, at 20. PEFC does not reserve places for particular stakeholders. Id. at $11,21$.

208. ForestEthics, SFI: Certified GreenWash: Inside the Sustainable Forest Initiative's Deceptive Eco-Label 4 (2010), available at http://forestethics.org//sites/forestethics.huang.radicaldesigns.org/files/SFI-Certified-Greenwash-Report-ForestEthics.pdf (describing moderate ecologist's resignation from SFI board); Meidinger, supra note 169, at 57 (describing NatureConservancy's resignation from SFI board). 
changes in one standard often elicit countermoves from the other. ${ }^{209}$ The result has been a Silicon Valley-style standards war in which each side seeks to attract more retailers and suppliers than the other. Predictably, this competition has encouraged both standards to converge over time. Most of the changes on PEFC/SFI's side have been designed to reassure the public (and indirectly, retailers) that its standards are credible. This has led to various upgrades, such as giving non-AF\&PA members more power, strengthening compliance audits, ${ }^{210}$ and banning certain practices outright. 211 PEFC and SFI have also adopted FSC-style protections for workers, indigenous peoples, and local communities. ${ }^{212}$ Conversely, FSC has become more supplier-friendly. Changes include letting producers mix certified and uncertified wood, 213 and relaxing certain rules for "small and low intensity" forests. ${ }^{214} \mathrm{FSC}$ has also considered establishing local exceptions for Canadian, Russian, and tropical suppliers ${ }^{215}$ that would almost certainly reduce safety. ${ }^{216}$

209. Meidinger, supra note 169 , at 56, 78; see also Interview with Ben Gunneberg, Gen. Sec'y, PEFC (2004), available at $\mathrm{http}: / / \mathrm{www}$. forest.lt/pefc.Straipsnii_LT/Press/Ben\%20Gunneberg-apie $\% 20$ PEFC.doc (FSC and PEFC group compete but also influence each other).

210. Meidinger, supra note 169, at 55 (describing how AF\&PA responded to activist critics by making SFI independent and creating a multi-stakeholder board of directors); Brown \& Zhang, supra note 185, at 2056 (describing how SFI created an MSC-style expert advisory board to recommend improvements to existing standards); Meidinger, supra note 169, at 67,82 (describing how SFI added notice-and-comment requirements to rule-making); Berg \& Cantrell, supra note 184, at 33-34 (describing how SFI introduced mandatory audits for members who use its logo on packaging); UNECE, supra note 204, at 115 (describing how SFI implemented FSC-style chain-of custody procedures so that certified wood can be tracked from forest to store); MECHEL ET AL., supra note 194, at 10-12 (describing how FSC introduced detailed "chain of custody" procedures and required public disclosure of audit results).

211. MeCHel ET AL., supra note 194, at 48-49 (describing how individual PEFC national bodies authorized old growth logging and use of genetically modified organisms); Rotherham, supra note 200, at 16 (describing PEFC's Sustainable Forest Management Requirements).

212. Meidinger, supra note 169 , at 62 ; Wortman, supra note 76; Visseren-Hamakers \& Glasbergen, supra note 192 , at 412 .

213. Mechel et al., supra note 194, at 49; Purbawiyatna \& Simula, supra note 180, at 36. FSC still has a zero tolerance policy for producers that violate traditional or civil rights, fail to observe high conservation values, practice illegal logging, convert natural forest to plantations, or plant genetically modified trees. Purbawiyatna \& Simula, supra note 180 , at 42 . See also MECHEL ET AL., supra note 194, at 36.

214. The special rules are limited to a relatively small number of obligations to promote worker safety, local services, and local communities, and to prevent, mitigate, and repair negative impacts on environmental values. FSC INTERNATIONAL, supra note 171, at 10.

215. Meidinger, supra note 169 , at $66 \mathrm{n} .84$.

216. Id. at 67 . 
The result of these changes is that-on paper at least ${ }^{217}$-current SFI and PEFC's standards have become nearly indistinguishable. ${ }^{218}$ Despite this, both organizations continue to fight. This seems wasteful. ${ }^{219}$ Several governments have urged FSI and PEFC to recognize each other-although so far without result. ${ }^{220}$ Some observers predict that governments and green building advocates will eventually force unification by recognizing both standards equally. ${ }^{221}$

Interactions With Government. Western governments originally saw FSC as a replacement for failed diplomatic initiatives ${ }^{22}$ and a chance

217. Activists claim that PEFC's regulations are looser in practice. MECHEL ET AL., supra note 194 , at 11-12.

218. Compare FSC, FSC Principles and CRiteria for Forest Stewardship 15 (2012) [hereinafter FSC PRINCIPLES] (FSC Principle 6: "The Organization shall maintain, conserve and/ or restore ecosystem services ... and shall avoid, repair or mitigate negative environmental impacts") with PEFC, PEFC InTERnational Standard: Requirements For Certification SCHEMES" 8 (2010) [hereinafter PEFC INTERNATIONAL] (PEFC International Standard: Criterion 1: "[A]im to maintain or increase forests and other wooded areas and enhance the quality of the economic, ecological, cultural and social values of forest resources, including soil and water"); compare FSC PRINCIPLES, supra note 218, at 16 (FSC Principle 5: "The Organization shall use local processing, services, and value add[ed] ... . The Organization shall demonstrate commitment through its planning and expenditures to long-term economic viability.") with PEFC INTERNATIONAL, supra note 218, at 12 (PEFC International Standard Criterion 5: "Forest management planning shall ... give due regard to the role of forestry in rural development, and especially consider new opportunities for employment" including "training and employment of local people, including indigenous people, a preference for the local processing of timber and non-wood forest products, etc." It also "shall promote the long-term health and well-being of communities within or adjacent to the ... area."); compare FSC PRINCIPLES, supra note 218, at 13 (FSC Principle 2: Gender equality, occupational health and safety practices, meet or exceed minimum forest industry wages, resolving grievances through engagement with workers) and FSC Principles, supra note 218, at 14 (Principle 3: "Recognize and uphold the legal and customary rights of indigenous people to maintain control over management activities within or related to the Management Unit to the extent necessary to protect their rights, resources, lands and territories.") with PEFC INTERNATIONAL, supra note 218, at 12 (PEFC Criterion 5: "[L]egal, customary and traditional rights . . . shall be clarified, recognised and respected;" "disputes should be handled according to processes or just and fair resolution; "in the interim, provide meaningful opportunities for parties to be engaged in forest management decisions whilst respecting the processes and roles and responsibilities laid out in the policies and laws where the certification takes place.").

219. See, e.g. Rotherham, supra note 197, at 610 ("As only $9 \%$ of the world's forests have been certified it seems that the focus should be on expanding the number of FSC-approved standards and increasing the area of certified forests and not on attacking the competition.").

220. Purbawiyatna \& Simula, supra note 180 , at 22, 76, 78 (citing statements by Switzerland, the European Parliament, and the G8); Programme for the Endorsement of Forest Certification Schemes, wHYFSC, http://www.whyfsc.com/index1.asp?menu=7\&sub=102 (last visited May 22, 2014) ("The committee concludes that it would hope to see the approach and standard used by FSC becoming the target for all other certification schemes, such as PEFC.").

221. UNECE, supra note 204, at 113.

222. Büthe, supra note 15, at 22 (The Austrian government supplied "a substantial part" of FSC's start-up costs after developing countries and domestic business interests forced it to repeal a ban on tropical wood imports). 
to exert influence beyond their borders. ${ }^{223}$ Conversely, host governments supported PEFC as a counterweight that empowers local elites.224 Specific tactics include grants, public praise, treating private standards as prima facie compliance with local law, ${ }^{225}$ adopting government procurement policies that favor certified wood, ${ }^{226}$ and green construction codes that track (and sometimes conflict with) FSC or PEFC standards. 227 In recent years, however, many officials have begun promoting certification in general ${ }^{228}$ without endorsing any specific standard.229 This may be because FSC and PEFC have largely converged. Alternatively, officials could be ideologically inclined to "let the market decide" 230 or feel constrained by international treaties. ${ }^{231}$ Governments have also learned from private standards to update their own regulations. ${ }^{232}$

Results. As of 2011, 9.6\% percent of the world's forests were certified. ${ }^{233}$ About two-thirds (62\%) followed PEFC. ${ }^{234}$ Certification is

223. Forest Certification, supra note 170 , at 12 (Austrian, Dutch, and Mexican financial support); PurbawiYatna \& Simula, supra note 180, at 44 (Danish, German, Dutch, and Swedish financial support).

224. Purbawiyatna \& Simula, supra note 180 , at 45.

225. Meidinger, supra note 169 , at 59 .

226. This is particularly important in Europe where government purchases account for eleven percent of GDP. Visseren-Hamakers \& Glasbergen, supra note 192, at 416.

227. UNECE, supra note 204, at 113.

228. Visseren-Hamakers \& Glasbergen, supra note 192, at 416. Press Release, UNECE, Governments-Significant Actors for Certification of Sustainable Forest Management (Oct. 4, 2005), available at http://www.unece.org/press/pr2005/05tim_p07e.html; PurbawiYatna \& Simula, supra note 180, at 21-22.

229. Purbawiyatna \& Simula, supra note 180 , at 75 (Denmark accepts FSC, PEFC and SFI); PEFC, PEFC ANNUAL REVIEw 2011 16 (2011), available at http://www.pefc.org/resources/ brochures/organizational-documents/982-annual-review-2011 (all national procurement policies accept PEFC); MECHEL ET AL., supra note 194, at 6 (UK recognized PEFC and SFI after they addressed certain shortcomings); How to Check FSC and PEFC Certification of Timber and Wood Products, CPET, http://www.cpet.org.uk/files/Category\%20A\%20Practical\%20Guide\%20 to $\% 20$ Checking\%20Certificates.pdf (last visited May 22, 2014) (UK accepts all three standards); PEFC, Facts and Figures, http://www.pefc.org/about-pefc/who-we-are/facts-a-figures (last visited May 22, 2014) ("PEFC certification is a standard of choice for public timber procurement [including in] the United Kingdom, Germany, and Japan."); PurbawiYatna \& Simula, supra note 180, at 75-76 (Belgium deems FSC and PEFC acceptable), 76 (Switzerland recognizes FSC and PEFC), 76 (Japan recognizes FSC, PEFC, SFI; New Zealand does not endorse any scheme over others) and 76-77 (Germany accepts FSC and the PEFC but not SFI); MECHEL ET AL., supra note 194, at 23, 25-26 (Netherlands is developing certification system similar to FSC). Many governments permit suppliers to show sustainability without any standard at all. Purbawiyatna \& Simula, supra note 180, at 10 (UK, Denmark, Germany, Japan and France and New Zealand).

230. Purbawiyatna \& Simula, supra note 180 , at 75.

231. MECHEL ET AL., supra note 194, at 7-8 (Constraints include the WTO Agreement on Government Procurement and various EU Directives).

232. Meidinger, supra note 169 , at 78 .

233. UNECE, supra note 204, at 109; Rotherham, supra note 197, at 610. 
now widespread in Europe (57\%) and North America $(32 \%)^{235}$ but has made little progress in the tropics, where profit margins are thin and the required reforms are costly.236 At current growth rates, it will be eighty years before half of the world's forests are certified. ${ }^{237}$

As in our coffee and fisheries examples, the key economic fact seems to be that most consumers prefer certified wood but are unwilling to pay a premium. ${ }^{238}$ This has encouraged large oligopolists in the home improvement, ${ }^{239}$ paper, ${ }^{240}$ and home construction ${ }^{241}$ industries to defend their market share by offering certified products. ${ }^{242}$ The net result is that certification has become nearly universal across the twenty-seven percent of U.S. forestland owned by large timber companies like Weyerhauser with smaller firms providing additional supplies as needed.243 Many retailers seem to have shifted some or all of their compliance costs onto these firms. 244

The story outside oligopoly markets is very different. There, firms have no choice but to buy wood at the lowest possible price.

234. UNECE, supra note 204 , at 109

235. Id.

236. Purbawiyatna \& Simula, supra note 180, at 17, 21, 27 (small and medium-sized tropical suppliers cannot afford certification); MECHEL ET AL., supra note 194, at 14, 37 ("comparatively huge investments" will be needed to meet FSC standards in the tropics). PEFC has been handicapped by the fact that national forestry associations are rare in the tropics. PurbawiYatna \& Simula, supra note 180 , at 28.

237. UNECE, supra note 204, at 109.

238. PurbawiYatna \& Simula, supra note 180 , at 11 (while retailers and consumers give "preferences to sustainably produced timber," suppliers doubt their willingness to pay premiums that cover costs); Meidinger, supra note 169, at 76-77 ("very few" retail consumers are willing pay price premiums); Forest CerTIFICATION, supra note 170, at 8 (same).

239. The home improvement/do-it-yourself industry was extraordinarily concentrated in the early 2000s, with the two largest firms-Home Depot and Lowes-possessing seventy-one percent of the market. Sasser, supra note 173, at 237.

240. AF\&PA members include disproportionate numbers of "large pulp and paper operations." Stephen Harris \& Rene Germaine, Improving Forest Management Through the Supply Chain: an Assessment of Wood Procurement Managagement Systems in the Forest Products Industry in Forest Policy for Private Forestry, supra note 176, at 264-65. Paper products account for about half of North American (54\%) and world (52\%) wood products consumption. UNECE, supra note 204 , at 85 .

241. The top five homebuilding firms account for $29 \%$ of new construction. Two of these firms adopted sustainability standards in the early 2000s. Sasser, supra note 173, at 237.

242. Purbawiyatna \& Simula, supra note 180 , at 82 (quoting WalMart executive's statement that "shifting to sustainable timber has not added one single penny to the price of our tissue").

243. As of 2003 , roughly one in five small mills belonged to SFI. Harris \& Germaine, supra note 240 , at 263 (quoting self-reported survey data).

244. Auld et al., supra note 170, at 277 (Only $30 \%$ of surveyed landowners expect to receive a premium for certified wood); Purbawiyatna \& Simula, supra note 180, at 11 (Tropical suppliers do not believe that retailers will pay premiums that cover certification costs.). 
Thousands of small U.S. mills and private forests provide the uncertified wood needed to meet this demand. ${ }^{245}$

Certification has almost certainly increased conservation efforts in participating forests. ${ }^{246}$ These added compliance costs range from a few percent of revenue for lumber to perhaps ten percent for pulpwood. ${ }^{247}$ This figure is not much smaller than the nineteen percent "tax" that government regulation is thought to impose on the U.S. economy. ${ }^{248}$

\section{Theory of Private Politics (I): Perfect Information}

Our five examples are inherently anecdotal. Policy requires a deeper and more general understanding. We proceed as follows. Section $A$ builds on our examples to explain how modern supply chains generate private power and define voting rules. Section B describes the social and economic forces which determine how big corporations exercise that power. We argue that many private standards are designed to please a shadow electorate of consumers and employees. Section $\mathrm{C}$ looks at how private and public political systems interact and can sometimes strengthen each other.

245. Press Release, Int'l Wood Mkts. Grp., Canada \& U.S. "Top 20" Lumber Producers' Report Indicates Renewed Industry Optimism (March 21, 2013) (Top 5 producers produce $31 \%$ of U.S. lumber; top 20 produce $58 \%$.); Harris \& Germaine, supra note 240 , at 259 (Most forest products firms purchase their wood fiber needs from small brokers and loggers on the open market).

246. See, e.g., Meidinger, supra note 169, at 77 (Forest certification has produced "improved environmental and social practices in many parts of the world"); MECHEL ET AL., supra note 194, at 10 (2006) (Analysis of Corrective Action Requests suggests that FSC has improved forest management).

247. Information on compliance costs can be found in Auld et al., supra note 170, at 278 (More than eighty percent of forest owners believe certification expenses, increased administrative burdens, and operating restrictions are significant); PurbawiYatna \& Simula, supra note 180 , at $31 \mathrm{n} .11$ (Forest certification costs $\$ 0.50 /$ hectare per year rising to $\$ 1 /$ hectare every five years with additional chain of custody costs totaling $\$ 500$ per assessment regardless of acreage); Ralph J. Aug et al., Land Use Changes Involving Forestry in the United S rates: 1952 to 1997, With Projections to 205091 (2003) (defining "timberland" as land that produces at least 20 cubic feet/acre/year); Density of Woods, SI METrIC, http://www.simetric.co.uk/si_ wood.htm (last visited May 23, 2014) (hard- and softwood volumes per metric ton); Changyou Sun \& Henry W. Kinnucan, Economic Impact of Environmental Regulations on Southern Softwood Stumpage Markets: A Reappraisal, 25 S. J. A pPLIEd Forestry 108 (2001) (prices per ton). In practice, timber lost to operating restrictions in certified forests is almost completely replaced by new production from uncertified forests. Brown \& Zhang, supra note 187, at 2061-63. However, this fact cannot erase the environmental gains from private regulation unless we assume that new logging occurs on land that is even more vulnerable than the land that FSC takes out of service. Id. This seems implausible.

248. Devin Bowen, Cost of Government Day 6 (2012), available at http://costofgovern ment.org/files/files/COGD2012_hi\%20res.pdf. 


\section{A. Private Power and Voting Rules}

Private power only occurs in special circumstances. Tellingly, all five of our examples involve corporate supply chains. ${ }^{249}$ But just where does corporate power come from? The central fact, in the words of one observer, is that suppliers are afraid to defy "a huge retailer they can't afford to lose."250 The more careful answer is that private power works best in industries where suppliers must incur large up-front investments ("fixed costs") to sell goods at a small mark-up. ${ }^{251}$ Here, the key point is that suppliers must maintain consistently high sales volumes to earn a profit. The rub, of course, is that large customers can change suppliers at any time. When this happens, the supplier immediately starts to lose money. Big customers often maximize this leverage by deliberately focusing their purchases on a small group of preferred suppliers. Suppliers who fail to deliver exceptional price and quality - or, in our case, to observe standardslose their status and are immediately terminated. ${ }^{252}$

So far, we have considered transactions between individual buyers and sellers. But many large retailers insist that their suppliers practice the same ethics for everyone they sell to. ${ }^{253}$ This forces standards onto buyers who never agreed to and may even oppose them. Finally, we have said that suppliers need a minimum sales volume to remain profitable. When enough customers request the standard, scale economies in the non-compliant product disappear. At this point the private standard becomes universai. ${ }^{254}$ This critical mass defines our voting rule.

249. See generally Stephen M. Maurer \& Sebastian von Engelhardt, Industry Self-Governance and National Security: On the Private Control of Dual Use Technologies (UC Berkeley Goldman Sch. of Pub. Pol'y, Working Paper No. GSPP12-005, 2012), available at http:/papers.ssrn.com/ sol3/papers.cfm?abstract_id $=2189919$.

250. Wellik, supra note 47 ; see also Mayer \& Gereffi, supra note 15 , at 8 ("[F]irms with large market shares ... source from many smaller suppliers, each of which may have few options other than doing business with the lead firm.").

251. See generally Maurer \& von Engelhardt, supra note 249 . The nature of the investment does not matter so long as it requires large up-front (fixed) costs. Familiar examples include investments in plant equipment, training, and even learning how to serve the peculiarities of a specific customer.

252. The threat would not be credible if switching suppliers significantly increased the large firm's costs. Large firms can almost always avoid this fate by finding a new preferred supplier or by spreading purchases across multiple small suppliers.

253. Examples in the coffee sector include Sara Lee and Proctor \& Gamble. Kolk, supra note 125, at 230. Astra-Zeneca follows a similar policy in the pharmaceutical industry. STEPHEN M. Maurer, Regulation Without Government (2012). In many cases, no agreement is necessary. We have seen that suppliers often find it cheaper to adopt a single standard than to maintain duplicate facilities.

254. The tipping point occurs when industry-wide demand for the lower standard falls below the volume needed to support just one supplier. 
From Voting Rules to Outcomes. Voters in our simplest examples (tuna, food safety) developed standards through simple face-to-face negotiations. Here, the politics are obvious: The winning coalition must offer each member a closer approximation to its preferred standard than any other group. This simple analysis assumes perfect information. However, small voters cannot afford much face-to-face discussion. Instead, they will often base their decisions on incomplete information and advice from trusted intermediaries. ${ }^{255}$ This makes outcomes vulnerable to random misunderstandings and deliberate trickery. Procedures that establish orderly hearings and debate reduce this danger and make politics more predictable.

Delegation. So far, we have assumed that big customers exercise power directly. However, we have seen that firms often share power in exchange for information or to show transparency. In extreme cases, retailers may even cede power entirely. 256

This delegation clearly makes the recipients better off: Otherwise, they would not accept power in the first place. ${ }^{257}$ For this reason, we can be confident that any standard that includes, say, large numbers of ecologists really does improve the environment. At the same time, our argument says nothing about how the benefits are divided. Whether by luck or negotiating skill, some parties will normally receive more than others.

Legitimacy. The economics of private power place hard limits on what private goverance can accomplish. First, voting rules often require supermajorities. ${ }^{258}$ This is arguably undemocratic since it blocks many outcomes that a conventional government would pass by majority vote. At the same time, we can be sure that whatever private initiatives do go forward have broad support. In this sense, the average private standard is almost always more democratic than the average public one.

255. See Oliver E. Williamson, Markets and Hierarchies: Analysis and Antitrust IMPLICATIONS (1975).

256. There have been several cases where large purchasers of nanotechnology and artificial DNA products called on suppliers to self-govern without demanding specific terms. This makes sense for industries where designing a standard requires arcane knowledge. Stephen M. Maurer, Five Easy Pieces: Case Studies of Entrepreneurs Who Organized Private Communities for a Public Purpose (UC Berkeley Goldman Sch. of Pub. Pol'y, Working Paper No. GSPP 2010-11, 2010), available at $\mathrm{http}: / /$ papers.ssrn.com/sol3/papers.cfm?abstract_id=1713329\%20.

257. This is only true over the long run; in the short term, players may tolerate unfavorable outcomes so long as their expected benefit is positive.

258. This is offset by the fact that votes are denominated in dollars so that big companies have more power than small ones. Despite this, our examples suggest that private governance often requires buy-in from perhaps a half-dozen firms. 
Second, no delegation is irrevocable: The big corporations can take back power whenever they like. This suggests that private power cannot yield outcomes that consistently frustrate the dominant companies. Even so, private power gives society more chances for collective action than it had before. Courts should welcome this.

Finally, suppliers and NGOs that accept delegated power often protest that they deserve more generous terms. But this only shows that their alternative options are limited. Giving these groups more access to formal government would automatically expand their private leverage as well.

\section{B. Private Politics: The Players}

We have emphasized that private standards are enforced by big corporations. This section asks how well their preferences track popular opinion. We consider three polar cases.

Perfect Markets. We start with the classical limit in which competition forces firms' economic profits to zero. ${ }^{259}$ Here, the usual argument that companies are irresponsible "because they only care about money" cannot be right. Indeed, a company that fails to invest $\$ 1.00$ in precautions to avoid $\$ 1.05$ in expected losses will soon go broke. Still, the complaint contains a grain of truth: Companies in perfectly competitive markets cannot afford to adopt purely voluntary or optional methods. If they do, new entrants will flood in to undercut them. This means that competitive markets can only address problems for which society has already defined a price. This can happen either because consumers are willing to pay more for compliant goods or suppliers believe that accidents will lead to higher regulatory burdens and/or legal liability. ${ }^{260}$

Oligopoly Markets and Shadow Electorates. Price competition in real markets is often suppressed. However, this does not mean that competition is dead. In many markets, firms will still compete to sell more units at the stabilized price. This is almost always done by offering consumers non-cash benefits. These can be utilitarian (e.g. higher quality), psychic (e.g. celebrity endorsements), ${ }^{261}$ or social (e.g. sus-

259. "Economic profit" is equal to the "accounting profit" that appears on balance sheets less opportunity costs, i.e. what the investor could have earned by investing in her second-best business opportunity. Profit (Economics) WIKIPEDIA, http://en.wikipedia.org/wiki/Profit_(economics) (last vistied May 23, 2014).

260. For the classic statement of deterrence theory, see U.S. v. Carroll Towing Co., 159 F.2d 169 (2d Cir. 1947). For an analysis of how the risk of regulatory backlash affects corporate behavior, see Maurer \& von Engelhardt, supra note 249.

261. David Vogel, The Market for Virtue: The Potential and Limits of Corporate SoCIAL Responsibility 49 (2005); Mayer \& Gereffi, supra note 15, at 9-10. ("When demand for 
tainable production). We have seen that consumers are often willing to switch brands over social issues. This can produce spectacular losses in profitability and share prices. ${ }^{262}$

This competition for market share turns consumers into a kind of shadow electorate. The good news is that the resulting vote is reasonably democratic in the sense that the customers who buy popular brands (StarKist) or patronize national retailers (Home Depot) are almost identical to the voters who turn out for federal elections. ${ }^{263}$ The bad news is that this shadow electorate seldom faces clear choices. Instead, consumers' purchasing decisions almost always reflect a complex mix of self-interest (quality), intangible psychic benefits (celebrity endorsement), and public policy (environmental values). That said, these problems are not very different from conventional elections where voters are asked to make policy choices based on an uncertain mix of social responsibility (e.g. building new schools), individual self-interest (avoiding new taxes), and psychic values (candidate charisma).

Non-monetary benefits are also important on the cost side. Scholars have shown that corporate social initiatives often improve the bottom line through higher morale and productivity, ${ }^{264}$ increased ability to attract talented workers, ${ }^{265}$ and less employee turnover. ${ }^{266}$ This suggests that corporate employees often constitute a second shadow electorate alongside consumers.

a product is less a function of observable utility than of constructed brand identity, firms are more vulnerable to social pressure."); Tanja Borzel et al., Racing to the Top? Regulatory Competition Among Firms in Areas of Limited Statehood, in Governance Without State 144, 147 (Thomas Risse ed., 2011) ("[O]nce a firm starts engaging in self-regulation . . competitors will have strong incentives to follow suit for fear of losing market shares").

262. ConRoY, supra note 45, at 12 (Nike's revenue fell by sixteen percent and its stock price by fifty-seven percent following media criticism in 1997-98.); Fuchs, Khalfagiannini, \& Arendtsen, supra note 49 at 40 (Criticism of Kenyan labor and pesticide policies produced significant "market losses for UK retailers.").

263. The 2013 hacking attacks against Target affected 70-110 million customers or about onethird of the U.S. population. Monica Langley, Inside Target, CEO Struggles to Regain Shoppers' Trust, WALL ST. J. (Feb. 19 2014). This is only slightly smaller than the 80-130 million citizens who typically cast votes in U.S. national elections. Michael Tomasky, Turnout: Explains a Lot, ThE Guardian (Nov. 3, 2010, 7:18 AM), http:/www.theguardian.com/commentisfree/michael tomasky/2010/nov/03/us-midterm-elections-2010-turnout-says-a-lot (81.5m U.S. voters cast ballots in 2010 midterm election); Fed. Election Comm'n, Federal Elections 20125 (2012), available at http://www.fec.gov/pubrec/fe2012/federalelections2012.pdf (129.1m U.S. voters cast ballots in 2012 presidential election).

264. VOGEL, supra note 261 , at 16 . Some observers claim that socially responsible corporations are able to pay lower wages although the evidence is controversial. Id. at 58 .

265. Id. at 56. Ninety-seven percent of business students claim that they would accept an average of fourteen percent lower income to work for companies with "a better reputation for corporate social responsibility and ethics." Id.

266. Id. at $57-58$. 
In principle, non-price competition can continue to the point where corporations spend all of their economic profit trying to please their consumers and/or employees. In this case, private regulation is only slightly less stringent than traditional government, which can ban products entirely.

Monopolists and Corporate Citizenship. Finally, suppose that firms suppress both price and non-price competition. Executives and shareholders must now decide whether to pocket their monopoly profit or else spend it to override market signals by, for example, paying abovemarket wages. Here, a relative handful of privileged executives exercise power based on a complex mix of greed, ethics, professional norms, peer pressure, ideology, and perceived social obligation. ${ }^{267}$ One could argue that this outcome is still preferable to no private action at all, particularly when the elites hold plausibly mainstream views. That said, U.S. antitrust law has traditionally rejected this possibility, and we ignore it in what follows.

Putting it Together. Perfect price competition leads to the familiar world of deterrence theory. Imperfect competition retains these incentives but also requires corporations to please shadow electorates of consumers and workers. This is by far the most democratic outcome. Finally, fully cartelized industries let executives ignore both signals. This provides a second, political reason to oppose cartels.

But these are special cases. More usually, real markets feature limited-but-imperfect competition that mixes all three scenarios. Here, corporate elites respond to a complex mix of liability fears, market share, and personal preferences. In this respect, corporate CEOs are not too different from elected officials who try to please the voters but also exercise significant discretion. Crucially, the balance can be inferred from market structure. Thus, we expect firms in competitive markets to act mainly from price signals, like expected liability, and oligopolists to pay attention to shadow electorates. Conversely, monopolists face few market constraints: We therefore expect them to act from personal and sometimes idiosyncratic beliefs.

\section{Interactions With Government}

We have seen that public and private regulation often proceed in parallel. The question remains whether these two channels can interact and strengthen each other.

267. Id. at 13 (firm managers can balance claims of shareholders, consumers, and the public with their own personal commitment to civic purposes). 
The Preemption Myth. Private regulation is often criticized as a cynical attempt to preempt government with weak measures that improve conditions in Industry A just enough so that regulators turn their attention to Industry B. However, this is no bad thing if government really does have limited resources and attention span. While Industry $A$ receives less attention, this is only because officials believe that Industry B's problems are now more urgent. On net, this sounds like an improvement. ${ }^{268}$

Similar arguments imply that some industries may never receive government attention. Here, private governance is the only game in town. In the words of former FTC Chairman Robert Pitofsky,

Self-regulation often may deter conduct that would be universally considered undesirable, but that the civil or criminal law does not prohibit. For example, cheating in sporting contests may not violate the law because the improper conduct is not considered sufficiently serious or because no injured party is likely to appear to bring suit. As a result, industry self-regulation may provide the only meaningful deterrent to would-be cross checkers and bean ball artists. ${ }^{269}$

A more troubling critique is that private standards can sometimes replace or override government outcomes. Indeed, our coffee, lumber, dolphin, and fish examples all began as attempts to evade a stalled diplomatic process. From this perspective, forcing the West's "embedded liberalism" onto global markets ${ }^{270}$ smacks of colonialism. This objection can only be overcome by making private governance at least as democratic as the official forums it displaces. Efforts by $4 \mathrm{C}$, FSC, and PEFC to include local elites are a long step in this direction.

Interactions. Information exchange can only happen where private and public standards coexist. ${ }^{271}$ Given that the two channels willand indeed must-interact, we should worry that one may suppress the other.

For companies, private governance is about cost. From this standpoint, developing a private standard provides a hedge in case the official regulation turns out to be inadequate, or late, or never arrives at all. But as time goes by, firms learn more. If the public standard ap-

268. Pitofsky, supra note 12 ("[E]nforcement agencies have demonstrated in their case selection and advisory opinions that they are not in the business of challenging legitimate and wellintentioned self-regulation . ...").

269. Id.

270. Mayer \& Gereffi, supra note 15 , at 4.

271. Id. at 17-18 (predicting "the emergence of multi-stakeholder governance in which public and private modes of governance interact and reinforce each other"). 
pears to be succeeding, companies may rationally decide to abandon the private channel altogether. ${ }^{272}$

Government always has the last word. If it wants to, it can ban private standards within national borders. For a large nation like the U.S. this will automatically cripple them abroad as well. Alternatively, government can promote private standards with grants, procurement regulations, and public encouragement ("jawboning"). Our examples suggest that governments have historically intervened based on ad hoc judgments that particular private initiatives would extend their power. However, future policymakers could well decide that private governance should be promoted as an end in itself. This might be based on a pragmatic hope that helping communities self-govern will displace chaos and extremism. Alternatively, officials could conclude that private democracy is inherently desirable on ideological grounds.

\section{Theory of Private Politics (II): Incomplete Information}

So far we have focused on how private politics translates individual preferences into collective action. However, democracy is only possible when voters know the costs and benefits associated with every possible standard. Our coffee and lumber examples suggest that these estimates are often wrong. Private political systems should be judged by their ability to develop information that avoids and corrects such mistakes. Professors Farrell and Saloner point out that this can be done either through conventional political debates or Silicon Valleystyle "standards wars." 273 It is an open question as to which arrangement works best. ${ }^{274}$

Section A explores how incomplete information leads to unbalanced standards that frustrate democratic outcomes. Section B analyzes how private political institutions ("Internal Politics") try to overcome this problem. Finally, Section $\mathrm{C}$ argues that competition between multiple standards ("External Competition") can sometimes elicit information more efficiently and lead to better outcomes than institutions that rely exclusively on internal politics.

\section{A. Imperfect Information and "Unbalanced" Standards}

Democratic decisionmaking is critically dependent on knowing (a) how many suppliers will adopt a particular standard, and (b) how the

272. This dynamic is partly offset by the fact that the cost of completing the private standard falls over time.

273. See Farrell \& Saloner, supra note 3.

274. Id. 


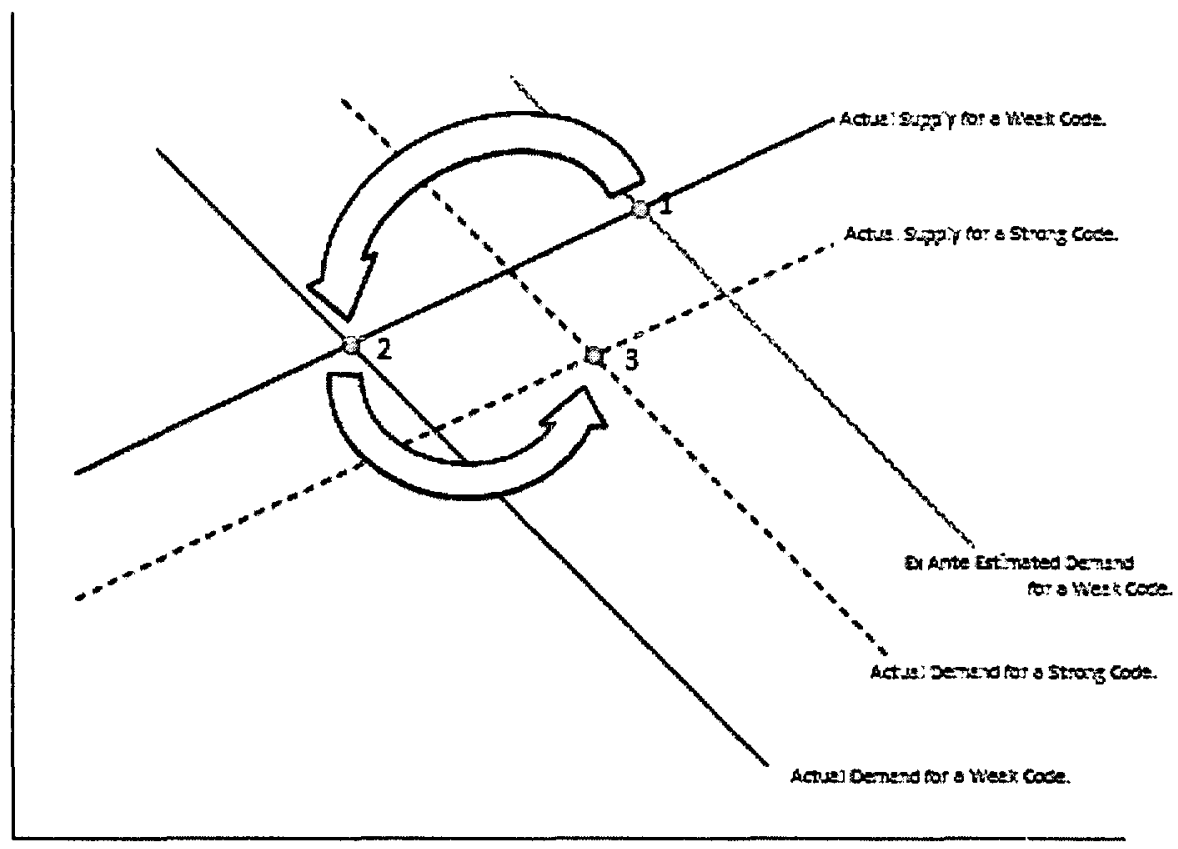

FIG. 1

costs of regulation will be shared among suppliers, retailers, and consumers. ${ }^{275}$ In principle, this information is encoded in the certified product's supply and demand curves. However, these are poorly known and what information does exist is closely guarded.

Figure 1 presents a generic analysis of the problem. Suppose suppliers and retailers agree to pursue a specific standard. Their expected costs and rewards assume that supply and demand will intersect at some particular point, say Point 1 . If this prediction is correct, every supplier who implements the standard will find a buyer willing to pay the expected premium. Politically, everyone gets what they bargained for. However, we have seen that real standards often generate more supply than demand (4C, SFI) and vice versa (FSC). This situation is unstable, since suppliers who earn nothing from the standard will eventually drop out so that supply and demand come into balance at Point 2. This, however, implies a radically different set of benefits and burdens than the parties anticipated. Institutions that find themselves in this predicament will often want to take corrective action. For example, parties who find themselves at Point 2 could adopt a new and

275. Retailers and suppliers can only subsidize standards to the extent that they earn positive (economic) profit. 
tougher standard with the goal of establishing a new equilibrium (Point 3), which is closer to the parties' democratically-agreed target (Point 1).

This cycle of error-and-correction can delay or defeat democratic choice. The question remains whether better institutions can fix the problem. To the extent that human knowledge is limited, the answer is almost certainly "no." The case is different, however, where suppliers and buyers possess asymmetric information and are tempted to deceive each other. Our five examples suggest that such effects are often important. On the one hand, the fishing, lumber, and coffee examples suggest that suppliers are almost always forced to subsidize the cost of new standards. ${ }^{276}$ This gives them an obvious incentive to claim poverty or, in terms of Figure 1, to mislead retailers into thinking that the supply curve for strong standards is weaker than it really is. Conversely, our coffee example suggests that big retailers can trick suppliers into investing in standards by overstating predicted demand so that suppliers end up subsidizing retailers. ${ }^{277}$ Private political institutions should be organized to reduce these information asymmetries and expose trickery as much as possible.

\section{B. Internal Politics}

The simplest politics take place within a single institution that debates, implements, and updates standards over time. Political debate provides an obvious strategy for overcoming information asymmetries. For example, we expect advocates to selectively reveal information that favors their standard. This forces opponents to disclose additional information as a corrective, which can potentially ignite still more rounds of disclosure and counter-disclosure. The net result is that debate elicits more information than the actors would voluntarily disclose. Information can also be revealed through miscalculation. This is particularly likely when members share confidential information as a way of developing trust. Finally, employees may deliberately ignore their employers' interests from personal conviction or to express solidarity with the collaboration. These loyalties may be purely

276. This statement is not true of competitive industries where suppliers earn zero (economic) profit. In this case, we expect companies to leave the market instead of paying subsidies.

277. Even if suppliers later abandon the new standard, their compliance still confers a temporary benefit on retailers. More importantly, some suppliers may never revert at all if the cost of maintaining the new standard is low or changing standards is expensive. This is especially true where the baseline standard provides a stepping stone so that higher and more lucrative standards become affordable. 
psychological or a calculated attempt to build outside business relationships. ${ }^{278}$

\section{External Politics}

Our food and lumber examples suggest that competing standards are common. ${ }^{279}$ In many ways the situation resembles a political election, with each side trying to build a community of retailers and suppliers around its proposal. At the same time, there are important differences. First, retailers can recognize more than one standard at a time. This lets them experience several standards before selecting a winner. Second, standards can evolve. This means that the eventual winning standard may look very different from the players' original proposals. Finally, the contest does not end until some critical mass of retailers decides that competition is no longer in their interest. This could happen because retailers decide that there is little left to learn or that a unified standard will be cheaper and more effective. At the same time, our forestry and food examples show that rival standards can persist indefinitely.

External competition also has drawbacks. First, political actors are split into two camps. This means that each competing group has less information to draw on. Second, there are fewer political differences within each group and, therefore, less incentive to invest in the political debates that generate new information. Finally, we expect competing institutions to attack each other. Negative attacks that depress one standard's popularity without raising the other's weaken both sides.

On current evidence, it is hard to say whether external politics works better than internal politics or vice versa. That said, the forestry and food standards seem to have undergone more frequent (and substantial) changes than tuna, fisheries, or coffee. Pending further evidence, courts should be open to the possibility that external politics is an efficient way to promote democratic outcomes.

\section{Current LaW}

This section reviews the law of private power. Part A begins with common law and constitutional limits. These are almost entirely procedural. Part B explains how the Sherman Act places substantive lim-

278. For a description of cross-cutting loyalties in commercial open source, see Stephen $M$. Maurer, The Penguin and the Cartel: Rethinking Antitrust and Innovation Policy for the Age of Commercial Open Source, 2012 UTAH L. Rev. 269 (2012).

279. The synthetic gene industry similarly features two private standards and one public one. MAURer, supra note 253 . 
its on acts that affect competition. Finally, Part $\mathrm{C}$ examines Sherman Act cases that limit private power for political reasons that have nothing to do with markets or economic efficiency.

\section{A. Common Law}

Common law courts regulate private power under various theories. Past and present association members usually claim "advantages incident to membership" under contract and fiduciary duty law. ${ }^{280}$ Nonmembers can similarly sue under tort theories including assault, defamation, and interference with economic advantage. ${ }^{281}$ Finally, both groups can invoke constitutional theories where private associations perform "governmental functions by the sufferance of the state." 282

In practice, almost all of the case law focuses on procedural defects. Most notably, private rulemaking must follow previously announced procedures that provide for notice, comment, reasoned debate, and majority vote. ${ }^{283}$ Private enforcement proceedings must similarly offer notice and good-faith hearings. ${ }^{284}$ The stringency of these requirements depends on what is at stake. Thus, actions to protect industry must carefully consider the public interest and the accused's right to

280. Hatley v. Am. Quarter Horse Ass'n., 552 F.2d 646, 655 (5th Cir. 1977).

281. Note, Developments in the Law: Judicial Control of Actions of Private Associations: The Traditional Theories, 76 HARv. L. Rev. 998, 1000-01 (1963).

282. Id. at 63.

283. Gilder v. PGA Tour, Inc., 936 F.2d 417, 424 (9th Cir. 1991) (Directors cannot change existing rules to achieve a specific result in a pending matter.); Charles $\mathrm{O}$. Finley \& $\mathrm{Co}$., v. Kuhn, 569 F.2d 527, 544 (7th Cir. 1978) (Organization cannot adopt rules in "disregard" of its own "charter or bylaws."); Hennessey v. NCAA, 564 F.2d 1136, 1147 (5th Cir. 1977) (Rulemaking satisfied due process where organization followed its own procedures, conducted careful study and deliberation, gave notice to affected parties, and held majority vote.). A fortiori, rules adopted by supermajorities command more deference. Hennessey, 564 F.2d at 1147 (noting that by-law was changed by "greater than majority vote").

284. Lindemann v. Am. Horse Shows Ass'n, 624 N.Y.S. 2d 723, 727 (1994) (criticizing "pro forma" hearings and "arbitrary," "capricious," or "pretextual" exercises of discretion); Hatley, 552 F.2d at 654-55 (Organization must hold hearings where enforcement depends on subjective determination or discretion.); Jackson v. Am. Yorkshire Club, 340 F. Supp. 628, 632 (N.D. Iowa 1971) (Principles of "natural justice" require notice, hearing, and an opportunity to defend oneself.). Cases discussing good faith include: Charles $O$. Finley, 569 F.2d 527 at 540 (Hearings must be conducted "in good faith, after investigation, consultation and deliberation" and should not be an "abrupt departure" form past practice or a "change of policy."); STP Corp. v. U.S. Auto Club, 286 F. Supp. 146, 170 (S.D. Ind. 1968) (Private rules enforcement must follow "rudimentary due process procedures" and any actions must be "reasonable, done in good faith, and ... not discriminatory."); Gilder, 936 F.2d at 424 (Board of Directors owes members a fiduciary duty and has duty to act "in the best interests of the corporation" and not for "private gain."); and Lindemann, 624 N.Y.S. 2d at 727 (1994) (rejecting "pro forma," "arbitrary," "capricious," and "pretextual" hearings). 
earn a living or operate a business. ${ }^{285}$ Conversely, courts are more deferential when the private association possesses "specialized competence," 286 the accused has countervailing power, ${ }^{287}$ or there is no conflict of interest. ${ }^{288}$ Though courts hardly ever say so, this willingness to balance strongly suggests that judges see private governance as valuable and legitimate. ${ }^{289}$

At the same time, these common law hurdles are modest: Private associations willing to adopt near-copies of the Federal Rules of Civil Procedure or the Administrative Procedure Act are almost certainly safe from scrutiny.290 With the exception of dolphin-safe tuna, all of our private rule-making examples feature elaborate charters that meet this test. While courts often say that they are prepared to strike down

285. Falcone v. Middlesex Cnty. Med. Soc'y, 170 A.2d 791, 799 (N.J. 1961) (Association holding "a virtual monopoly over the use of local hospital facilities" must act in a "reasonable and lawful manner" in the interests of "the medical profession and the public generally."); Carroll v. Int'l Bd. of Elec. Workers, 31 A.2d 223, 225 (N.J. Ch.1943) (Union rules that admitted certain members "as juniors with no yoice in the affairs of the union" violated right to earn a livelihood.); Meyer v. Nebraska, 262 U.S. 390, 399 (Liberty interest included "the right of the individual to contract, to engage in any of the common occupations of life."); James v. Marinship Corp., 155 P.2d 329, 335 (Cal. 1944) (Unions holding "a monopoly of the supply of labor" occupied "a quasi-public position similar to that of a public service business" and had "certain corresponding obligations."); Jackson, 340 F.Supp. at 630 (N.D. Iowa 1971) (Membership in private association was "necessary and vital to a profitable purebred hog breeding program."); Lindemann, 624 N.Y.S.2d at 725 (1994) ("The arbitrary action of a private association is not immune from judicial scrutiny ... where there is a showing of 'economic necessity' for membership and 'monopoly power' over the profession."); Marjorie Webster Junior Coll., Inc. v. Middle States Ass'n of Colls. \& Secondary Sch., Inc., 432 F.2d 650, 655 (D.C. Cir. 1970) ("[A]ppellant does not wield such monopoly power over the operation of educational institutions that its standards for accreditation may be subject to plenary judicial review.").

286. Marjorie Webster Junior Coll., 432 F.2d at 658.

287. See Restatement of Torts $\& 765$ (1939); see also Restatement (Second) of Torts $\$ \S 767,768$ (1977); Marjorie Webster Junior Coll., 432 F.2d at 658 (Plaintiff could organize its own accreditation body.).

288. Note, Developments in the Law: Judicial Control of Actions of Private Associations: Association Action Affecting Nonmembers, 76 HARv. L. Rev. 1037, 1046-47 (1963) [hereinafter Association Action Affecting Nonmembers] (Courts are "less sympathetic" where there is an "apparent self-serving interest in the standards and the lack of a well-established tradition of self-policing.").

289. Courts also accept lower standards where more burdensome procedures could deprive organizations of "the ability to promote ... specific social goals generally believed to be desirable." Note, Developments in the Law: Judicial Control of Actions of Private Associations: Framework for the Judicial Inquiry, 76 Harv. L. Rev. 990, 991 (1963) [hereinafter Framework for the Judicial Inquiry].

290. Government is invariably cited as the gold standard for private regulation. Hatley v. Am. Quarter Horse Ass'n., 552 F.2d 646, 654-55 (5th Cir. 1977) (Procedural protections for private associations are "something akin to traditional due process."); Lindemann v. Am. Horse Shows Ass'n, 624 N.Y.S. 2d 723, 730 (1994) (Private association which controlled equestrian sports did not qualify as state action but was nevertheless obligated to follow the "earmarks" of due process and observe procedures "congruent" with conventional review by a government agency). 
substantive rules that conflict with "the law of the land," "settled public policy," "good morals," "fairness,"291 or "minimum rationality,"292 they hardly ever act on these sentiments. ${ }^{293}$

\section{B. The Sherman Act (I): Protecting Markets}

Congress limits private economic power through the antitrust laws. Case law since the 1960s almost always focuses on protecting markets. This includes procedural requirements to confirm that rulemaking is a genuine attempt to solve problems rather than an excuse to suppress competition. More recent cases have added a broad hint that private standards cannot limit competition to achieve "ethical goals" that lack any well-defined market price.

Procedural Requirements. Congress has authorized various industries to self-regulate even where the resulting rules would normally violate the Sherman Act. However, the Supreme Court's Silver decision holds that these rules are only valid if they "further[ ] legitimate self-regulative ends." 294 In particular, private bodies must adopt sufficient procedures to confirm that private rules are genuinely designed to address industry problems and not just an excuse to suppress competition. ${ }^{295}$ This includes requiring notice-and-hearing procedures to weed out "unsupportable accusations," giving dissenters the chance to present evidence of ulterior motive, and generating a record for antitrust review. ${ }^{296}$ Courts have since extended Silver to cases where pri-

291. Hatley, 522 F.2d at 655 (Association policy cannot conflict with "good morals," the "bounds of reason," "common sense," "fairness," state law, or "public policy."); Charles O. Finley \& Co., v. Kuhn, 569 F.2d 527, 544 (7th Cir. 1978) (Rules cannot conflict with "the law of the land."); Falcone v. Middlesex Cnty. Med. Soc'y, 170 A.2d 791, 800 (N.J. 1961) (striking down actions that "run[] strongly counter to the public policy of our State and the true interests of justice"); Framework for the Judicial Inquiry, supra note 289, at 997 (Social policy is only invoked in the "clearest cases" and where private rules would require members to "commit crimes" or prevent them "from performing public duties such as serving on juries."); James v. Marinship Corp., 155 P.2d 329, 337 (Cal. 1944) (Private rules cannot be contrary to "public policy," conflict with state or federal law, and, in some states, common law precedents where "the law has definitely set its face."); Jackson v. Am. Yorkshire Club, 340 F. Supp. 628, 632 (N.D. Iowa 1971) (Private rules must be "reasonable," "pursuant to the rules and laws of the organization," "in good faith," and not in "violation of the law of the land.").

292. Hennessey v. NCAA, 564 F.2d 1136, 1144 (5th Cir. 1977). This does not mean that they must be "perfectly suited" or "perfectly fair" but only "rationally related to that objective, and free from arbitrariness and invidious discrimination. Id.

293. But see James, 155 P.2d at 342 (overturning union rule against admitting black members); Carroll v. Int'l Bd. of Elec. Workers, 31 A.2d 223, 225 (N.J. Ch. 1943) (Public policy required unions to be "democratic" and admit all who are "reasonably qualified for their trade.").

294. Silver v. N.Y. Stock Exch., 373 U.S. 341, 358 (1963).

295. See id.

296. Id. at $364-65$. 
vate rules are needed to create a market, promote competition, or increase output under the Rule of Reason. ${ }^{297}$

For the most part, these requirements seem indistinguishable from the preexisting common law rules. ${ }^{298}$ For example, rulemaking must follow basic notice-and-comment procedures ${ }^{299}$ and be done in good faith, ${ }^{300}$ while enforcement similarly requires adequate notice and hearing ${ }^{301}$ and good faith. ${ }^{302}$ However, there is some indication that

297. See, e.g., Broadcast Music, Inc. v. CBS, 441 U.S. 1 (1979). For an authoritative summary of how courts have applied Silver, see Denver Rockets v. All-Pro Management, Inc., 325 F. Supp. 1049, 1065 (C.D. Cal. 1971).

298. But see Hatley v. Am. Quarter Horse Ass'n., 552 F.2d 646, 654-55 (5th Cir. 1977) (Failure to provide hearing violated state due process but not Sherman Act).

299. Jackson v. Am. Yorkshire Club, 340 F.Supp. 628, 635 (N.D. Iowa 1971) (Rulemaking body must follow its own rules and regulations.); Gunter Harz Sports, Inc. v. U.S. Tennis Ass'n., Inc., 511 F. Supp. 1103, 1122 (D. Neb. 1981) (Association was required to provide "notice and comment procedure[s]" sufficient "to inform those potentially affected" and "allow interested parties to be heard"); Id. (Association was required to hold fair hearings that considered both "favorable and unfavorable evidence" so that excluded products "were given a fair trial"); Id. (Silver does not require rule-making procedures to be a "model of procedural due process" and may not require any hearing at all.); E. A. McQuade Tours, Inc. v. Consol. Air Tour Manual Comm., 467 F.2d 178, 188 (5th Cir. 1972) (Fact that tests were "unsophisticated and poorly done, and the data poorly preserved" was irrelevant absent evidence of collusion, bias or bad faith.); M\&H Tire Co., Inc. v. Hoosier Racing Tire Corp., 733 F.2d 973 984, (1st Cir. 1984) (Selecting a tire was "essentially [a] business judgment" that did not "call[ ] for elaborate quasijudicial procedures like those suitable in cases of penalties, discipline, or suspension."); Am. Fed'n of Television and Radio Artists. v. Nat'l Ass'n of Broads., 407 F. Supp. 900,902 (S.D.N.Y. 1976) (finding that rule was justified where concern was not "frivolous" even though "science" did not rise to a "mathematical certainty").

300. $M \& H$ Tire, $733 \mathrm{~F} .2 \mathrm{~d}$ at 984 (Procedures need only be adequate to assure that selection is made "in good faith," "non-collusively," and "with equal consideration" of competing products.).

301. E. A. McQuade Tours, 467 F.2d at 188 ("[A]11 interested tour operators were on notice of the rules."); Livezey v. Am. Contract Bridge League, 1985 U.S. Dist LEXIS 16058, at *42 (E.D. Pa. Sept. 12, 1985) (Rule of reason claim was "weaken[ed]" where plaintiff received a hearing with "many procedural safeguards."); McCreery Angus Farms v. Am. Angus Ass'n, 379 F. Supp. 1008,1019 (S.D. Ill. 1974) ("Ordinarily, the member seems entitled to notice of the charges and an opportunity to present and time to prepare his defense."); Denver Rockets, 325 F. Supp. at 1066 (Disciplinary proceedings should include at least a "rudimentary hearing" that let an individual "petition for consideration of his specific case."); Blubaugh v. Am. Contract Bridge League, 2004 U.S. Dist. LEXIS 3178, at *27 (S.D. Ind. June 20, 2001) (same); McCreery, 379 F. Supp. at 1010-11, 18 (Member should have right "to meet [charges] if he can in a full, fair, and open hearing" and confront his "actual accuser."); Tropic Film Corp. v. Paramount Pictures Corp., 319 F.Supp. 1247, 1253 (S.D.N.Y. 1970) (noting existence of "clear and pre-announced standards," an "appeal system ... permitting written presentation and oral argument," and a "detailed procedure" for same); but see Blalock v. LPGA, 359 F. Supp. 1260, 1268 (N.D. Ga. 1973) (In dictum: Hearing was unnecessary where decision was "virtually a mathematical application of pre-determined standards.").

302. Deesen v. PGA, 358 F.2d 165, 169 (9th Cir. 1966) ("PGA is entitled to adopt reasonable measures" in deciding applicant was qualified to play professional golf); but see Blalock, $359 \mathrm{~F}$. Supp. At 1265 (Suspension was imposed as an act of "completely unfettered, subjective discretion ... without hearing from plaintiff" by "competitors ... who st[ood] to gain financially from 
the antitrust laws demand slightly higher procedural standards for rules that affect competition directly. ${ }^{303}$ As before, formal government procedures provide the gold standard for private governance. ${ }^{304}$

The requirements are also subject to balancing. Thus, Silver's requirements cannot be so burdensome that they "undermine" the association's "very authority . . . to impose sanctions." 305 Conversely, courts require more elaborate procedures when the private association wields "tremendous economic power" 306 or controls the right to

plaintiff's exclusion from the market."); E. A. McQuade, 467 F.2d at 188 ("Nor were the rules applied to McQuade arbitrarily or discriminatorily."); McCreery, 379 F. Supp. at 1010-11, ("Those who conduct the hearings and make the decisions must be unbiased and maintain open minds until they have heard the whole story in open hearings with the challenged member."); Brenner v. World Boxing Council, 675 F.2d 445, 456 (2d Cir. 1982) ("Neither can we conclude that the executive committee which suspended Brenner was composed of competitors who stood to gain from his suspension."); Jackson, 340 F.Supp. at 635-36 (Decisionmakers must weigh evidence "in good faith" and "not in malice" or a desire for "personal vindication."); Blalock, 359 F. Supp. at 1267 (criticizing "completely unfettered, subjective and discretionary determination of an exclusionary sanction by a tribunal wholly composed of competitors"); Blubaugh, 2001 U.S. Dist. LEXIS 8187 , at $* 27$ (noting that plaintiff been given "the opportunity to challenge committee members for cause"); cf. Deesen, 358 F.2d at 169 (There was, however, no evidence that a single member could control the process to enforce personal agenda or that committees have ever discriminated against applicants for personal reasons.).

303. Eliason Corp. v. Nat'l Sanitation Found., 614 F.2d 126, 130 (6th Cir. 1980) (Rules should be periodically revised to reflect new technologies.); Denver Rockets, 325 F. Supp. at 1066 (Rule that required professional players to go to college where some did "not desire" or even have "the mental and financial ability to do so" was overbroad.); $M \& H$ Tire Co., 733 F.2d at 984 (Rule-making must be open to the entire industry and "all interested companies.").

304. Blubaugh, 2001 U.S. Dist. LEXIS 8187 , at $* 24-25$ (The law does not require private disciplinary procedures "to be a blend of the Federal Rules of Civil Procedure ... with constitutional and procedural protections afforded to criminal defendants."); McCreery, $379 \mathrm{~F}$. Supp. at 1010 ("This does not imply that the same technical judicial standards as exist in Court trials must be applied to Association rules and hearings."); Brant v. U.S. Polo Ass'n, 631 F.Supp. 71, 77 (S.D. Fla. 1986) (Suspended polo player had "the opportunity to be heard and defend himself in a context which, while perhaps not comporting with the rigors required by due process in a court of law, were sufficient to enable him to present his side of the incident."); but see McCreery, 379 F. Supp. at 1010-11 (criticizing "[o]ld, ad hoc, informal and pro forma committee procedures bordering on the arbitrary" as "outmoded and dangerous").

305. Justice v. NCAA, 577 F. Supp. 356, 381 (D. Ariz. 1983); Silver v. N.Y. Stock Exch., 373 U.S. 341, 363 n.15 (1963) (Procedural protection for non-members would not "burden" or slow the exchange under the circumstances because it already operated similar protections for members.); Jackson, 340 F.Supp. at 635-36 ("The directors must, of course, also consider the interests of [their organization]" when considering action that affects member's livelihood.).

306. Silver, 373 U.S. at 361. 
pursue a business. ${ }^{307}$ Once again, these balancing approaches imply that private standards are legitimate and deserve deference. ${ }^{308}$

Substantive Limits on Self-Regulation. Section 1's Rule of Reason famously invites parties to adopt restrictions that enhance competition more than they harm it. Though difficult to apply, the basic concept is clear so long as all costs and benefits are priced on the open market. The problem comes when private rules attempt to balance "both monetary and ethical" 309 goals. Since the latter have no established market, balancing is impossible unless and until someone attaches a price tag.

Prior to the 1970s, courts avoided this issue in two ways. First, judges refused to apply the antitrust laws to noncommercial entities. ${ }^{310}$ This meant that many restrictions were never examined at all. This exception disappeared when the Supreme Court's Goldfarb ${ }^{311}$ decision acknowledged that professional societies often pursue com-

307. Brenner, 675 F.2d at 456 (Restraint was unreasonable where suspension was effected by appellees to prevent him from engaging in his trade); McCreery, 379 F. Supp. at 1019 ("The complete control of the registered purebred Black Aberdeen Angus breeding business by the Association means in effect that the Plaintiffs are completely out of the business of raising and selling purebred registered Black Aberdeen Angus cattle while they are under indefinite suspension."); Jackson, 340 F.Supp. at 635-36 (noting that member's "livelihood as a Yorkshire breeder is dependent upon membership"); Clarett v. NFL, 306 F. Supp. 2d 379, 406 (S.D.N.Y. 2004). (Sherman Act forbids any "contract which unreasonably forbids any one to practice his calling.").

308. Provided that procedures are adequate, Silver courts never second-guess private rules on substantive grounds. See, e.g., Jackson, 340 F.Supp. at 635 (Review was limited to "with the fairness of the hearing itself" and "no event would the Court substitute its judgment ... on the merits of the case); Blubaugh, 2001 U.S. Dist. LEXIS 8187, at $* 24-25$ (declining to make substantive determination beyond evaluating process or sufficiency of evidence); Livezey $v$. Am. Contract Bridge League, 1985 U.S. Dist LEXIS 16058, at*50 (E.D. Pa. Sept. 12, 1985); Gunter Harz Sports, Inc. v. U.S. Tennis Ass'n, Inc., 511 F. Supp. 1103, 1119 (D. Neb. 1981) (Rule upheld supporting findings had "objective basis" in fact); but see Lindemann v. Am. Horse Shows, 624 N.Y.S.2d 723, 743 (1994) (Sanction barring accused's spouse, family, employees and others from participating in events "would appear to be too broad a sanction in the absence of some showing of an attempt to bypass the original sanction.").

309. United States v. Or. State Med. Soc'y, 343 U.S. 326, 336 (1952) (emphasis added) (Professional society objected the insurance scheme and replaced traditional doctor-patient relationship with a "tripartite" arrangement that gave employers and insurance companies the right to review private medical records and influence choice of treatment.).

310. Jonathan E. Seib, Antitrust and NonMarket Goods: The Supreme Court Fumbles AgainNational Collegiate Athletic Association v. Board of Regents, 104 S.Ct. 2948, 60 WASH. L. REv. 721, 723 (1985); Wendy T. Kirby \& T. Clark Weymouth, Antitrust and Amateur Sports: The Role of Noneconomic Values, 61 IND. L.J. 31 (1985); Marjorie Webster Junior Coll., Inc. v. Middle States Ass'n of Colls. \& Secondary Sch., Inc., 432 F.2d 650, 654-55 (D.C. Cir. 1970) ("It is possible to conceive of restrictions on eligibility for accreditation that could have little other than a commercial motive .... Absent such motives, however, the process of accreditation is an activity distinct from the sphere of commerce; it goes rather to the heart of the concept of education itself.").

311. Goldfarb v. Va. State Bar, 421 U.S. 773, 791 (1975). 
mercial goals for themselves and their members. Henceforth, the antitrust inquiry would depend on whether the "particular activities" at issue affected competition. Even so, the Court hinted that professions could still adopt restrictions "which could properly be viewed as a violation of the Sherman Act in another context" for valid, noncommercial ends. ${ }^{312}$

Second, judges refused to compare the value of economic and noneconomic goals. If the challenged restriction served some legitimate, non-market goal, they almost always found some way to uphold it. ${ }^{313}$ This changed after Professional Engineers, when the Supreme Court rejected a professional association's argument that bidding for fixed price contracts violated its professional ethics. ${ }^{314}$ Instead, the Court argued that "the Rule of Reason does not support a defense based on the assumption that competition itself is unreasonable" 315 and that any such exemption is "properly addressed to Congress." 316 Justices Blackmun and Rehnquist concurred but added that it was premature to "intimat[e]" that professional ethics could never "take account of benefits other than increased competition." 317

312. Id. at 788 n.17; Seib, supra note 310 .

313. Neeld v. NHL, 594 F.2d 1297, 1300 (9th Cir. 1974) (arguing that private rule's anticompetive effect was both "de minimis" and "incidental to the primary purpose of promoting safety"); Marjorie Webster, 432 F.2d at 654 ("[I]ncidental restraint of trade" by organizations dedicated to "the liberal arts and the learned professions" would not trigger antitrust liability "absent a purpose to affect commercial aspects of the profession"); Cooney v. Am. Horse Shows Ass'n, 495 F. Supp 424, 431 (S.D.N.Y. 1980) (Disciplinary action against owners accused of doping horses was not anticompetitive unless "the restraint is broader than reasonably necessary to accomplish the legitimate goal of the regulation."); Brenner v. World Boxing Council, 675 F.2d 445, 456 (2d Cir. 1982) (Sanctions against promoter were not anticompetitive because they "reasonably related to a policy justifying self-regulation."); Rooffire Alarm Co. v. Royal Indem. Co., 202 F. Supp. 166, 169 (E.D. Tenn. 1962) ("An association formed to foster high standards, to mitigate evils in trade existing through lack of knowledge or information, and to encourage fair competitive opportunities" did not violate Sherman Act "merely because it may effect a change in market conditions.").

314. Nat'l Soc'y of Prof'l Eng'rs v. United States, 435 U.S. 679, 696 (1978).

315. Id.

316. Id. at 689-90; see also United States v. Nat'l Ass'n of Broadcasters, 536 F. Supp. 149, 167-68 (D.D.C. 1982) ("Under established law, then, it would not matter if [defendant's] public interest arguments were correct... The enactment of the Sherman Act represents a basic policy decision regarding the centrality of competition in American commercial life. If there are to be exceptions from that policy in favor of other, different public interest considerations, they must be made-as occasionally they have been-by the Congress; they cannot be read into the antitrust laws by the courts in the guise of construction or interpretation."). For a modern argument that competition should respect ethical norms, see Cass R. Sunstein, Winner-Take-Less Codes: The Case of Private Broadcasting, 6 U. CHI. L. SCH. Roundtable 39 (1999) (arguing that Sherman Act should permit broadcasters to self-regulate violent or sexually explicit programming as a "'third way' between unlimited competition . . . and rigid governmental mandates").

317. Nat'l Soc'y of Prof'l Eng'rs, 435 U.S. at 699 (Blackmun, J., concurring). 
The Professional Engineers Court was clearly afraid of letting unelected judges decide which ethical values were important enough to trump the market. As Justice Powell later argued: "An antitrust policy divorced from market considerations would lack any objective benchmarks" 318 and would force courts to "determine what, if any, weight to give to noneconomic factors." 319 However, Justice Rehnquist was noticeably more expansive. He later argued that courts could still uphold ethical rules where the "restraint is not unreasonable in its effect on competition." 320 This left open the possibility that ethical goals could sometimes trump damage to competition. ${ }^{321}$

The Supreme Court made one last effort to resolve the issue in NCAA v. Board of Regents of the University of Oklahoma. ${ }^{322}$ However, the opinion was strangely ambivalent. On the one hand, the majority acknowledged that the association had important non-economic goals; on the other, this fact played no role in its reasoning. ${ }^{323}$ Instead, the majority argued that amateurism served an economic goal by making the college game more successful than "sports to which it might otherwise be comparable." 324 According to this Alice-in-Wonderland reasoning, the best way to make one market (college football) more economically efficient was to adopt rules that prevented a second market (professional athlete services) from forming at all.

The NCAA Court's focus on purely economic factors was so determined that most commentators, ${ }^{325}$ courts, ${ }^{326}$ and lawyers ${ }^{327}$ have as-

318. Continental T.V., Inc. v. GTE Sylvania, Inc., 433 U.S. 36, 53 n.21 (1977).

319. Kirby \& Weymouth, supra note 310 , at 32 .

320. Community Commc'ns Co., Inc. v. City of Boulder, 455 U.S. 40, 66 (1982). The opinion asked whether the Sherman Act should apply to municipalities. Rehnquist argued in dissent that forcing municipal officials to obey antitrust law would necessarily strip them of the right to legislate social regulations. Id. at 60 (Rehnquist, C.J., dissenting). Arizona v. Maricopa County Medical Society similarly avoided the issue by arguing that a medical society's attempt to fix prices was entirely unrelated to "public service or ethical norms." 457 U.S. 332, 349 (1982).

321. Professor Pitofsky has similarly suggested that the exception could apply where the impact on competition is de minimis. Pitofsky, supra note 12 (arguing that private ban on beer ads to college students would be permissible "since beer companies would retain many other avenues of advertising to attract the audience of legal buyers").

322. NCAA v. Bd. of Regents of the Univ. of Okla., 468 U.S. 85, 101-02 (1984).

323. Id.

324. Id. at 102.

325. James F. Ponsoldt, The Application of Sherman Act Antiboycott Law to Industry SelfRegulation: An Analysis Integrating Nonboycott Sherman Act Principles, 55 S. CAL. L. REV. 1, 22 (1981) ("Safety and other social policies not supported by legislation seem to have been rejected both as defenses in a Rule of Reason case and as arguments against the use of the per se rule."); Seib, supra note 310 , at 725 . ("The judiciary could not defer to what it might consider a higher value" even where the restraint on competition is "insignificant.").

326. Denver Rockets v. All-Pro Mgmt., Inc., 325 F. Supp. 1049, 1065, 1066 (C.D. Cal. 1971) (rejecting eligibility rule that forced players to complete college before turning professional: "However commendable this desire may be, this court is not in a position to say that this consid- 
sumed that antitrust law no longer considers non-economic goals at all. Yet the majority never quite says this. Moreover, White's dissent, which Rehnquist joins, argues that antitrust law should permit colleges to pursue "legitimate noneconomic goals" even when this impacts "the free market." 328 Based on this lingering ambiguity, many lower courts continue to supplement their purely economic analyses with alternative holdings that invoke ethical goals. ${ }^{329}$

Pricing Externalities. Even after NCAA, courts can still uphold private restrictions on externalities that might otherwise destabilize markets $^{330}$ or impose financial costs like court liability, new regulation, ${ }^{331}$

eration should override the objective of fostering economic competition which is embodied in the antitrust laws. If such a determination is to be made, it must be made by Congress and not the courts."); Law v. NCAA, 134 F.3d 1010, 1021-22 (10th Cir. 1998) (Restriction on hiring assistant coaches could not be justified by need to "open[] up coaching positions for younger people" or protect university budgets since "we may not consider such [social] values unless they impact upon competition.").

327. Pitofsky, supra note 12 ("[S]ome have cited [Professional Engineers], which can be interpreted to rule out consideration of non-economic goals . . . in a rule of reason analysis, as a threat to industry self-regulation.").

328. NCAA, 468 U.S. at 134 (White, J., dissenting).

329. Banks v. NCAA, 977 F.2d 1081, 1091 (7th Cir. 1992) (Alternate holding: NCAA rules provide a bulwark against the "quick buck" attitudes of professional sports, preserve a "proper focus" on education, and prevent colleges from being transformed into "minor league farm systems'" for the NFL); Gaines v. NCAA, 746 F. Supp. 738, 744 (M.D. Tenn. 1990) (The "overriding purpose" of NCAA eligibility rules is to "prevent commercializing influences" intruding on the "Athenian concept of a complete education." Such rules "may be judged or struck down by federal antitrust law."); Justice v. NCAA, 577 F. Supp. 356, 383 (D. Ariz. 1983) (Antitrust laws do not reach NCAA rules that are primarily noncommercial and "rooted in the ... protection of amateurism"); McCormack v. NCAA, 845 F.2d 1338, 1343 (5th Cir. 1988) (Student eligibility rules that serve "purely or primarily noncommercial objectives" held outside antitrust laws); Justice, $577 \mathrm{~F}$. Supp. at 379 (upholding rules which had no commercial purpose but "pertain solely to the NCAA's stated goal of preserving amateurism"); $c f$. NYNEX Corp. v. Discon, Inc., 525 U.S. 128, 136-37 (1998) (Antitrust laws only apply to acts done for "competitive reasons" and do not reach efforts to defraud regulators, "nepotism," "personal pique" and "business morality more generally."). Various FTC Commissioners have historically endorsed this view as well. Thomas B. Leary, Chairman, Fed. Trade. Comm'n, Self-Regulation and The Interface Between Consumer Protection and Antitrust (Jan. 28, 2004), available at http://www.ftc.gov/ public-statements/2004/01/self-regulation-and-interface-between-consumer-protection-and-antitrust (arguing that broadcast self-censorship "reflects a non-commercial value that. . . I would argue, and I think you will win if you argue . . the courts would uphold").

330. Almost all of these cases involve sports leagues that limit how much members can spend in order to preserve the on-field competition needed to attract fans. NCAA, 468 U.S. at 101-02 ("And the integrity of the 'product' cannot be preserved except by mutual agreement; if an institution adopted such restrictions unilaterally, its effectiveness as a competitor on the playing field might soon be destroyed."); Law, 134 F.3d at 1023-24 (In dictum: Limits on hiring assistant coaches might be justified to keep games "competitive" and "a marketable product"); $\mathbf{M} \& \mathbf{H}$ Tire Co., Inc. v. Hoosier Racing Tire Corp., 733 F.2d 973, 984 (1st Cir. 1984) (In dictum: Association could require members to purchase tires within a fixed price range "so that the number of participants would not dwindle"); Martin v. Am. Kennel Club, Inc., 697 F.Supp. 997, 1001 (N.D. Ill. 1988) ("[D]og shows could not function in the absence of rules regulating the conduct of participants."); Gunter Harz Sports, Inc. v. U.S. Tennis Ass'n, Inc., 511 F. Supp. 1103, 1117 (D. 
and (perhaps) lost public goodwill. ${ }^{332}$ However, the common feature of these judgments is that the externality will eventually suppress profits. ${ }^{333}$

This rationale is too limited to justify the kinds of open-ended interventions aimed at protecting the general public instead of shareholders. According to this reasoning, most if not all of our five examples should be illegal. And indeed, one might argue, following Rehnquist, that assigning price tags to these social impacts is best left to legislators. The trouble is that judges cannot really avoid setting price tags. Before the 1970s, courts always let ethics trump competition. This gave private ethical goals what amounted to an infinite price tag.

Neb. 1981) (upholding rule banning novel tennis rackets which "was intended to accomplish the legitimate goals of preserving the essential character and integrity of the game of tennis ... and preserving competition by attempting to conduct the game in an orderly fashion" and not an "intent to injure ... any . . . manufacturer or distributor of tennis equipment); Seib, supra note 310, at 733 (Athletic organizations can "impose regulations essential to protect the existence and integrity of their sport" including game rules, equipment standards, and safety regulations.); but see Clarett v. NFL, 306 F. Supp. 2d 379, 410 (S.D.N.Y. 2004) (League-wide rule excluding immature players was overbroad and should, at a minimum, be modified so that "each team could decide what level of risk it is willing to tolerate.").

331. Nat'l Soc'y of Prof'l Eng'rs, 435 U.S. 679, 696 n.22 (1978) ("Courts have, for instance, upheld marketing restraints related to the safety of a product, provided that they have no anticompetitive effect and that they are reasonably ancillary to the seller's main purpose of protecting the public from harm or itself from product liability."); see also Tripoli Co., Inc. v. Wella Corp., 425 F.2d 932, 937 (3rd Cir. 1970) (Restrictions on resale of caustic hair care products to general public were "reasonable" and "appropriate in the public interest" whether motive was to protect public or to avoid potential liability.); Neeld v. NHL, 594 F.2d 1297, 1300 (9th Cir. 1974) (upholding rule excluding one-eyed players: League's interest in avoiding personal injury liability is "[a]lso of some importance and legitimate concern." ); but see Clarett, 306 F. Supp. 2d at 408 (NFL rule designed to protect younger athletes from injury and over-training, though "laudable," could be "dismissed out of hand" since it had "nothing to do with promoting competition.").

332. Clarett, 306 F. Supp. 2d 409 (questioning whether NFL rule protecting young players could be justified as protecting the NFL brand); but see Molinas v. NBA, 190 F. Supp. 241, 244 (S.D.N.Y. 1961) (Recent scandals made it "absolutely necessary" for professional basketball "to exhume gambling from its midst . . . in order to survive."); $c f$. Brenner v. World Boxing Council, 675 F.2d 445, 456 (2d. Cir. 1982) (Sports leagues can adopt rules for "reasonable objectives" not limited to participant parity, safety, and league integrity.); Am. Fed. of Television \& Radio Artists v. Nat'l Ass'n of Broadcasters, 407 F. Supp. 900, 901-02 (S.D.N.Y. 1976) (Private standard was a "positive response" to criticism by U.S. senator, FCC, and private activists.); Tropic Film Corp. v. Paramount Pictures Corp., 319 F. Supp. 1247, 1249 (S.D.N.Y. 1970) (Movie industry could adopt voluntary rating system to avoid "an onslaught of legislative censorship.").

333. At least in theory, industry must take these costs at face value without, for example, placing a higher value on human life than judges or bureaucrats do. Ted Mann, Rail Safety and the Value of a Life, WALL ST. J. (June 17, 2013, 10:32 PM), http://online.wsj.com/news/articles/ SB10001424127887323582904578485061024790402 (Academic and government estimates place economic value of saving a life "about an order of magnitude" higher than wrongful death cases.). 
More recently, post-NCAA courts pretend to ignore ethics altogether. This prices the externality at zero. ${ }^{334}$

Starting from this zero-or-infinity choice, almost anything looks like an improvement. If firms set private limits on how much damage production does to the human or natural environment, judges should take industry's willingness to assume new burdens at face value. Of course, such decisions are self-interested and industry's suggested price could be much too low. But it is still an improvement over zero. A fortiori, this argument is even stronger where courts find that the body that produced the standard is sensitive to consumer preferences and/or has shared power with multiple stakeholder groups.

\section{The Sherman Act (II): Protecting Democracy}

Today's judges and scholars almost always analyze the Sherman Act in terms of economic efficiency. This is anachronistic. Microeconomic theory barely existed in $1890^{335}$ and was cluttered with uncertainty. Instead, lawmakers seem to have been far more interested in political arguments. ${ }^{336}$ Anglo-American political thought had long worried that private wealth would capture government and impose a plutocracy. ${ }^{337}$ The rapid growth of nationwide corporations in the late 19th Century convinced Congress that "[e]ven individually, some corporations were big enough to dominate state governments, and if they should combine among themselves, they might come to dominate the federal government as well." 338

But, in that case, when did economic power become a political threat? Sherman himself argued that:

If we will not endure a king as a political power we should not endure a king over the production, transportation, and sale of any of the necessaries of life. If we would not submit to an emperor, we should not submit to an autocrat of trade, with power to prevent competition, and to fix the price of any commodity. ${ }^{339}$

334. One could argue that the $N C A A$-style economic efficiency arguments are so elastic that modern judges have unfettered discretion to save almost any ethical rule they approve of. But this is hardly amounts to a principled or satisfactory legal doctrine.

335. Modern microeconomic theory is conventionally dated from publication of Alfred Marshall's Principles of Economics in 1890. The Sherman Act was passed the same year.

336. Richard Hofstadter, What Happened to the Antitrust Movement?, in Political Economy of the Sherman Act: The First One Hundred Years 20, 28 (E. Thomas Sullivan ed., 1991); see also David Millon, The Sherman Act and The Balance of Power, in Political Economy of the Sherman Act: The First One Hundred Years supra note 338, at 85.

337. Millon, supra note 336 , at 86.

338. Hofstadter, supra note 336 , at 28.

339. Theodore E. Burton, John Sherman 359 (1906), available at https:/archive.org/details/johnsherman017282mbp. 
However polemical, Sherman's rhetoric turned otherwise vague political concerns into an objective economic inquiry, i.e. whether the defendant could "dictate terms" or "command[] the price of labor." 340 Early Supreme Court cases echoed Sherman's theme by arguing that antitrust law was meant to stop "any one commodity" from falling "within the sole power and subject to the sole will of one powerful combination of capital." 341

The Supreme Court's Standard Oil decision introduced the Rule of Reason and shifted the focus to market efficiency. ${ }^{342}$ While the older plutocracy interpretation never disappeared entirely, it slowly faded as Americans got used to living with large corporations. But that is hindsight. In the 1930s and 1940s, the rise of Fascism with its emphasis on private control by worker-management councils breathed new life into the old fears. These crystalized in FOGA. ${ }^{343}$ While the Court could and did resolve the matter on conventional economic grounds, ${ }^{344}$ it did not stop there. Instead, it criticized private power more generally:

In addition to all this, the combination is in reality an extra-governmental agency, which prescribes rules for the regulation and restraint of interstate commerce, and provides extra-judicial tribunals for determination and punishment of violations, and thus "trenches upon the power of the national legislature" and violates the statute. ${ }^{345}$

This seemed to say that all private governance was illegitimate, at least when it included a government-like power to punish. Legal scholars took this as a sign that "[a]s the external impact of the standard setting becomes more severe ... a point has been reached where it appears that no private group is a safe repository for such quasi-

340. $I d$.

341. United States v. Trans-Mo. Freight Ass'n, 166 U.S. 290, 324 (1897).

342. Millon, supra note 336, at 86-87.

343. The Court did not articulate a policy argument against private self-governance, observing only that it "trenches upon the power of the national legislature." Ponsoldt, supra note 325, at 25. "This was arguably an indication by the Court of its intolerance for industry self-regulatory schemes of any kind." Id.

344. Fashion Originators' Guild, Inc. v. FTC, 312 U.S. 457 (1941). As the Court noted, paragraph 3 of the Clayton Act prohibits contracts that condition the sale of goods on agreeing not to use or deal in competing goods. Id. at 464 . It also found that restrictions that narrowed the outlets which manufacturers could sell to, the suppliers that retailers could buy from, and required Guild members to disclose the "intimate details of their individual affairs" violated Sherman Act $\S 1$. Id. at 465 .

345. Id. (quoting Addyston Pipe \& Steel Co. v. United States, 175 U.S. 211, 242 (1899)). 
governmental power." 346 However, it was hard for courts to define this "point" in any intelligible way. ${ }^{347}$

The difficulty in using political concepts to say when private power was and was not acceptable may explain why Justice Douglas reverted to Sherman's quasi-economic approach in his famous Columbia Steel dissent. Controlling steel prices, Douglas argued, gave "a handful of men" the power to wreck the economy. From this standpoint the "problem of bigness" was not just economic but also "a social menace":

[Private] power ... can be benign or it can be dangerous. The philosophy of the Sherman Act is that it should not exist. For all power tends to develop into a government in itself. Power that controls the economy should be in the hands of elected representatives of the people, not in the hands of an industrial oligarchy. Industrial power should be decentralized. It should be scattered into many hands so that the fortunes of the people will not be dependent on the whim or caprice, the political prejudices, the emotional stability of a few self-appointed men. . . . That is the philosophy and the command of the Sherman Act. It is founded on a theory of hostility to the concentration in private hands of power so great that only a government of the people should have it. ${ }^{348}$

The great advantage of the Sherman/Douglas approach was that it reduced a messy political judgment to a familiar and reasonably objective economic inquiry. Still, it was incomplete. Economic power sufficient to wreck the economy surely poses a political danger. But it is just as surely not the only danger. For this reason, Douglas' test failed to clarify $F O G A$ 's suggestion that smaller concentrations of power are likewise illegal.

Courts continued to echo FOGA's broad distrust of private power into the $1980 \mathrm{~s} .{ }^{349}$ Since then, most lawyers have come to assume that

346. Association Action Affecting Nonmembers, supra note 288, at 1047.

347. Justice Black's "trenches on the legislature" remark also seemed to suggest that private bodies could still regulate subjects not committed to Congress. The trouble in the 20th Century was that Congress could and did address almost everything. Among other things, this put thousands of private health and welfare standards off-limits.

348. United States v. Columbia Steel Co., 334 U.S. 495, 535-36 (1948) (Douglas, J., dissenting). Learned Hand made much the same point in the First Circuit's Alcoa decision: "We have been speaking only of the economic reasons which forbid monopoly; but, as we have already implied, there are others, based upon the belief that great industrial consolidations are inherently undesirable, regardless of their economic results. In the debates in Congress Senator Sherman himself ... showed that among the purposes of Congress in 1890 was a desire to put an end to great aggregations of capital because of the helplessness of the individual before them." United States v. Aluminum Co. of Am. (Alcoa), 148 F.2d 416, 428-29 (2d Cir. 1945).

349. Linseman v. World Hockey Association, 439 F. Supp. 1315, 1321 (1977) (criticizing private groups that "pool[] their economic power" to "substitute[] their own private government for the rule of the marketplace"); M\&H Tire Co., Inc. v. Hoosier Racing Tire Corp., 733 F.2d 
Justice Black's blanket condemnation of "private tribunals" would be phrased more narrowly today. 350 Doctrinally, courts have usually implemented this instinct by arguing that Justice Black's ban on government-style "tribunals" should not be read to include standards bodies that are "truly voluntary," 351 merely persuasive, 352 enforced solely by social norms ("naming and shaming"), ${ }^{353}$ or lack significant market power. ${ }^{354}$ Professor Elhauge has taken these arguments even further

973, 983 (1st Cir. 1984) ("We recognize that one of the evils of group boycott activity is that a private group may arrogate to itself quasi-judicial powers, a normally public function. In those situations where private groups are permitted to exercise such public powers, they may be required to afford fair and appropriate procedures."); Denver Rockets v. All-Pro Mgmt., Inc., 325 F. Supp. 1049, 1061 (C.D. Cal. 1971) 1061 (arguing that NBA members had "established their own private government"; the antitrust laws do not prevent private aggregations of power from existing, but do regulate "the use of private aggregations of power"); Blalock vs. LPGA, $359 \mathrm{~F}$. Supp. 1260, 1262 (N.D. Ga. 1973) ("[C]ombinations designed to influence coercively the trade practices of boycott victims" are per se unlawful even when there is no purpose "to eliminate them as competitors." (emphasis added)).

350. Pitofsky, supra note 12.

351. United States v. Nat'l Ass'n of Broadcasters, 536 F. Supp. 149, 164 (D.D.C 1982) (Rules that are voluntary in both theory and actual practice are not subject to the antitrust laws even when backed by the threat of public criticism.).

352. Tropic Film Corp. v. Paramount Pictures Corp., 319 F.Supp. 1247, 1254 (S.D.N.Y. 1970) (Distinguishing FOGA: Film ratings agreement was not designed to eliminate competition but only to advise exhibitors and the public of the films' content. Coercion was also absent); Costello Publ'g Co. v Rotelle, 670 F.2d 1035, 1047 (D.C. Cir. 1981) (Lower court should consider whether Catholic Church condemnation of book was an illegal boycott when enforcement was mediated by retailers' independent decision to stock it); Association Action Affecting Nonmembers, supra note 288 , at 1048 ("The case is substantially different where the association merely transmits findings to nonmembers or grants a seal of approval without itself attempting to enforce the standard. First, the dependence on nonmembers for the implementation of the standard introduces a possible check on its unreasonableness, and where these nonmembers are the ultimate consumers themselves, the problem of unchecked representation largely disappears. In addition, a new value-that of the free flow of information-appears in support of the action of the association.").

353. Tropic Film, 319 F.Supp. at $\mathbf{1 2 5 0}$ (noting that ratings were "entirely voluntary" and that newspapers and theatres would have refused to advertise X-rated films with or without formal ratings).

354. Law v. NCAA, 134 F.3d 1010, 1020 (10th Cir. 1998) (finding market power existed where contested rule had successfully depressed the the price of coaching services); Brant v. U.S. Polo Ass'n, 631 F. Supp. 71, 77 (S.D. Fla. 1986) (Suspension was too short to have any "palpable anticompetitive effect" on any relevant market.). A more doubtful version of the rule argued that associations could coerce their own members but not non-members. This must have been cold comfort to members who found themselves coerced after losing a 51-49 vote. Hennessey v. NCAA, 564 F.2d 1147, 1151 (5th Cir. 1977) ("The 'group boycott' cases typically have involved situations where there was some concerted refusal to deal with persons or companies because of some characteristic of those persons and companies. Here, the participants in the combinationthe colleges-remain free to deal with any of the persons in the 'target group'-the assistant coaches. The restriction rather depends upon a particular attribute of the participants themselves; namely, how many assistant coaches they have."); Coll. Athletic Placement Servs., Inc. v. NCAA, 1974 U.S. Dist. LEXIS 7050, at *8-10 (D.N.J. Aug. 22, 1974) ("The principle of the group boycott cases-that it is prima facie unreasonable for a dominant group to combine to 
by arguing that FOGA's criticism of "extra-governmental agenc[ies]" is limited to situations where actors have "financial interests that seem[ ] certain to bias their extra-governmental conduct." 355 Our five examples would almost certainly survive this test. Finally, some litigants have argued that Justice Black's objection should not apply where members of the executive branch have invited industry to selfregulate. Short of a congressional immunity statute, however, the law is unclear. ${ }^{356}$

\section{FOGA's Shadow}

The Justice Department and Federal Trade Commission concede that self-governance is often preferable to government regulation ${ }^{35 \%}$ and have repeatedly promised not to enforce FOGA against private standards bodies they approve of. ${ }^{358}$ Despite this, most private governance initiatives spend large amounts of time and energy studying antitrust concerns. ${ }^{359}$ This often leads to self-imposed limits that block action and complicate deliberation. ${ }^{360}$ It is reasonable to think that other private initiatives never form at all. These costs would be acceptable given a clear policy justification. However, we have seen that the actual case law is vague.

coerce"-did not apply where challenged restriction was designed to regulate member behavior and impact on third parties was "at best indirect.").

355. Einer Richard Elhauge, The Scope of Antitrust Process, 104 HARv. L. Rev. 667,742 (1991). Elhauge's proposal would be a sharp departure from Justice Douglas' Columbia Steel argument that the mere existence of private power is intolerable whether or not we expect it to be benign.

356. Nat'l Ass'n of Broadcasters, 536 F. Supp. at 168 (Expressing uncertainty over whether whether official approval is "an appropriate element for consideration in a Rule of Reason analysis."). Even assuming that government could confer immunity, the grant would also have to extend beyond general principles to address the specific provisions at issue. Id. at 169 .

357. Ponsoldt, supra note 325, at 1 n.1 (1981) (Justice Dept. policy holds " economic competition, not public or private regulation, is the most efficient form of economic organization." (quoting John Shenefield, Assistant Attorney Gen., Antitrust Div., Local Action and Professional Activites: Increased Antitrust Scrutiny, 1979 Bond Attorneys Workshop (Oct. 11, 1979))).

358. Leary, supra note 329 ("[I]t is unlikely that we will interfere with appropriately tailored industry efforts to restrict" the sale of "legal, but potentially harmful products to children.").

359. Kolk, supra note 124 (4C collaboration believed that any discussion of coffee prices would violate antitrust law); Jason Potrs, Multi-Stakeholder Collaboration for a SusTAINABLE COFFEe Sector 13-14 (May 2004), available at http:/www.iisd.org/pdf/2004/sci_coffee_background2.pdf (analyzing antitrust limits on 4C rule-making); F.A. Morris, A.M. Seward, and A.J. Kurzrok, A Nonproliferation Third Party for Dual-Use Industries - Legal Issues for Consideration, (Pac. Nw. Nat'l Labs. Report No. PNNL-21908 2012) (arguing that voluntary restrictions on nuclear technology sales do not violate the Sherman Act).

360. Auld et al., supra note 170 , at 280 (describing private trade association's belief that requiring members to purchase FSC lumber would violate Sherman Act); Kuenkel et al., supra note 114. Some producer countries have accused buyers of using competition policy as an excuse to avoid price negotiations. Auld et al., supra note 170 . 


\section{ViI. Reforming Private Governance Law}

Modern law insists that private self-governance must: (a) observe minimal due process protections; (b) refrain from any intervention that raises prices or reduces output in the name of non-market "ethical" issues; and, more controversially; and (c) never exercise coercive power rising to the level of an extra-judicial tribunal.

In practice, the first rule sets a low bar and seldom causes difficulties. However, the second and third rules are different. Since the Supreme Court's NCAA decision, judges have repeatedly evaded the second rule by pretending that ethical rules are pro-competitive. Similarly, Justice Black's rule against non-government tribunals has dissolved into metaphysical inquiries about when economic power becomes coercive. The net result is that antitrust law does not even try to address the central question of when private power is legitimate.

This article returns to the courts' traditional instinct that private power has value and deserves deference. In particular, we argue that the Sherman Act should respect whatever mix of private and public power best implements mainstream public opinion. Section A describes how relatively small changes to doctrine can implement this principle. Here, the main insight is that judges should expect corporations facing strong price or market share competition to be reasonably democratic. This is a fortiori true when corporations deliberately share power with other affected parties. Following the old Sherman/ Douglas agenda, the proposed rule reduces vague political fears to objective inquiries into membership and market structure. Section B suggests additional subsidiary tests that courts can deploy to decide when private governance is sufficiently democratic to receive deference.

\section{A. Rationalizing Antitrust Law}

This section argues that small doctrinal changes can rationalize existing case law. In keeping with our earlier discussion, ${ }^{361}$ we discuss the Sherman Act's procedural, economic efficiency and political doctrines separately.

Procedural Protections. We have argued that clear and orderly procedures reduce the cost of obtaining and processing information and make private politics more predictable. Silver and the common law cases that preceded it meet this goal reasonably well. Moreover, our examples suggest that modern initiatives are so exquisitely rule-bound that procedural challenges are rarely an issue. The main remaining 
defect of these doctrines lies in the courts' assumption that government-style procedures set the gold standard for building democratic institutions. However, our examples suggest that external politics or delegation can likewise improve democracy. Government-style procedural rules may be less necessary in these circumstances. This is particularly true when industry shares power with groups that can be reliably counted on to oppose cartelization. ${ }^{362}$

Protecting Competition. The Supreme Court's NCAA opinion has convinced most lawyers that private rules should avoid non-market ethical goals as much as possible. In economic terms, this amounts to valuing all externalities at zero. From a policy standpoint, this is a catastrophe. Externalities are, after all, a market defect. If the Rule of Reason permits rules that make markets possible, it should equally permit rules that make them more efficient.

Even so, judges' caution is understandable. Firms could, after all, invent sham externalities to disguise otherwise illegal cartels. Still, this seems unlikely in the typical case where an industry standard limits the harms that production is allowed to inflict on the human or natural environment. Examples include private standards that require companies to pay workers a living wage, purchase credits for carbon emissions, and avoid operations in environmentally sensitive areas.

All of these cases add to production costs and are therefore likely to raise prices or cut production. But this is only because the previously unpriced externality is now reflected in the true cost of production. Absent very special facts, such standards are unlikely to support cartelization. ${ }^{363}$ More often, companies will earn less than they did before. ${ }^{364}$ Judges should take this as strong evidence that companies are sincere. This is a fortiori true when the usual Silver procedures have been satisfied or fierce market share competition empowers a shadow electorate of consumers and employees.

Protecting Democratic Government. FOGA assumes that private self-governance is inherently inferior to public institutions. But if we

362. Leibowitz, supra note 17 ("If a board is more than simply a group of competitors, but includes others who would be harmed by an anticompetitive agreement then that makes it less likely that a particular rule is a result of a private agreement to restrict competition.").

363. For example, an industry with two production technologies $A$ and B could place an astronomical price tag on pollutants that are uniquely associated with process B. Similarly, von Engelhardt and Maurer show that increasing industry costs can sometimes support high prices by preventing new firms from entering the market. See Maurer \& Engelhardt, supra note 249.

364. Leary, supra note 329 ("When you have a compelling social concern, when the alternative to private regulation may be even more heavy-handed government regulation, when you are actually asking your members to do something that is against their immediate economic interest-not in aid of it-I think there is a narrow window for consideration of non-economic values in trade association codes and standards."). 
care about democracy, it should not matter where we find it. Justice Black was wrong to fear government in private hands. The real sin is putting government in unrepresentative hands.

This article has argued that the Douglas/Sherman agenda was on the right track: In order to be workable, limits on private political power must first be translated into some reasonably objective inquiry. Our proposed doctrine holds that antitrust law should never interfere on political grounds where corporations are strongly constrained by price or market share competition. Here, corporate views are almost certain to reflect fear of liability and/or strong shadow electorates. Conversely, judges should continue to fear private power when price and quality cartels let executives impose their personal views on the market.

Even without these conditions, courts should still respect private decisionmaking where industry shares power with other affected groups. Of course, delegation can always be rescinded, and groups can walk away. While delegation lasts, however, courts should assume that outcomes endorsed by corporations, environmentalists, and NGOs benefit all of these groups and are to that extent legitimate. Admittedly, courts must still be able to detect and ignore sham delegations to a few tame or token members. ${ }^{365}$ One very useful benchmark will be to ask whether private politics attracts more (and more diverse) participants than official hearings. ${ }^{366}$

Reducing political concerns to objective questions of market structure or delegation is bound to be controversial. However, these objections are best evaluated by asking how democratic particular initiatives really are. For now, our examples suggest that many, and perhaps most, private standards should be upheld.

Conflicting Traditions? Finally, we note that the Sherman Act's pro-market and pro-democracy traditions can occasionally conflict, most notably when private standards establish a national market that displaces state-by-state regulation. ${ }^{367}$ The advantage of our proposed

365. Leibowitz, supra note 17 ("Now, I don't think that board full of industry competitors becomes diverse with the addition of a single stray 'public' member who may, or may not, be engaged in the board's rulemaking; but it is hard to say in the abstract when the composition of a state board is sufficiently diverse that the board does not have to be supervised to have recourse to the state action defense.").

366. The range of companies that showed up to debate private biosafety standards for artificial DNA was noticeably broader in the public channel. MAURER, supra note 253 . They also included more non-Americans. Id.

367. Eliason Corp. v. Nat'l Sanitation Found., 614 F.2d 126, 129-30 (6th Cir. 1980) (Development and enforcement of nationwide health and sanitation standards for refrigerators was procompetitive because it allowed complying manufacturers "to be reasonably sure that they will 
reforms is that they resolve NCAA's ban on ethical rules and FOGA's ban on private tribunals traditions in exactly the same way: By recognizing that private power can be democratically legitimate. This suggests that judges should respect private standards so long as they appear to be reasonably democratic. State officials who nevertheless object can push back by enacting regulations to overrule the private result.

\section{B. Assessing Legitimacy}

Announcing doctrine is only the beginning. Over time, courts will also develop tests to decide when doctrine is satisfied. Our examples suggest four possibilities.

External Politics. We have seen that that external politics often reveal the costs and benefits of private standards faster and, to that extent, more democratically than traditional institutions. Courts should be open to this possibility. The fact that the winning standard is controlled by a narrow group should not matter if it has been repeatedly rewritten to compete with other standards.

Transparency. Transparency maximizes corporate incentives to respect public opinion. All else equal, a group that debates its standards in full view of the press and competitors deserves more deference than one that does not. ${ }^{368}$ In the words of former FTC Commission Jon Leibowitz: "A board is acting more like a government agency than simply a group of competitors when it works in the open." Conversely, a board that acts behind closed doors "is more likely indistinguishable from any other group of competitors." 369

Government Endorsement. Traditional government often sees private governance as an instrument for extending its influence. It seems singularly unjust to punish private parties for complying with these wishes. Worse, punishment is the quickest way to guarantee that no private party will ever cooperate again. Depriving traditional government of such a useful policy lever frustrates the will of the people and is inherently undemocratic. To be sure, one might worry that officials will ask the private sector to do things that would be unconstitutional if the government acted directly. In that case, the better solution is to

not have to modify their product in order to meet the different requirements of many jurisdictions.").

368. One synthetic DNA group called an open meeting to debate and vote on its final standard. Outside attendees included U.S. government officials, companies working on a competing standard, and a reporter from Nature. MAURER, supra note 253.

369. Leibowitz, supra note 17. See also, Pitofsky, supra note 12 (explaining that broadcasters' decision to make self-governance process public "enhances the credibility of the program"). 
limit officials' discretion to request cooperation in the first place. The bottom line is that government should also be able to endorse specific goals whenever it could regulate directly. Once this happens, courts should defer. ${ }^{370}$

\section{CONCLUSION}

The explosion of private governance since the 1990s has pushed participating companies into a legal limbo. This is patently unfair and undercuts a policy lever that government officials say they want. Somehow, John Sherman's attempt to protect public institutions from private power has produced a doctrine that cripples both.

One set of issues involves the Rule of Reason. This article has argued that businesses can almost always be trusted to place a price tag on externalities. The Supreme Court should confirm that NCAA does not prevent private associations from confronting ethical problems and externalities.

The other, deeper question is what to do with the Sherman Act's tangled political interpretation. FOGA's great simplifying conceit was that no private power is ever legitimate. But if we care about democracy, it should not matter where we find it. The genius of the Sherman/Douglas tradition is that it transformed nebulous fears of plutocracy into a well-defined economic inquiry. The problem, like many bright line tests, is that it is incomplete. This article has argued for an updated doctrine, which holds that corporations facing strong price or market share competition are at least as answerable to shadow electorates as the average elected politician. Alternatively, private standards bodies that fail to meet this test should still be allowed to legitimize themselves by convincingly sharing power with others.

As usual, courts will need new tests to implement these doctrines. Broad delegation, transparency, and government endorsement should all be strong "plus factors" in deciding when private governance is legitimate.

370. Our lumber example shows that this defense should not exist where government statements are non-specific and leave room for radically different interpretations. 